Brazilian Journal

of Chemical

ISSN 0104-6632

Engineering

\title{
AnSBBR WITH CIRCULATION APPLIED TO BIOHYDROGEN PRODUCTION TREATING SUCROSE BASED WASTEWATER: EFFECTS OF ORGANIC LOADING, INFLUENT CONCENTRATION AND CYCLE LENGTH
}

\author{
D. A. Santos ${ }^{1}$, J. A. D. Rodrigues ${ }^{2 *}$, S. M. Ratusznei ${ }^{2}$ and M. Zaiat ${ }^{1}$ \\ ${ }^{1}$ Departamento de Hidráulica e Saneamento, Escola de Engenharia de São Carlos, Universidade de São Paulo (USP), \\ Av. Trabalhador São-Carlense 400, CEP 13.566-590, São Carlos - SP, Brasil. \\ ${ }^{2}$ Departamento de Engenharia Química e de Alimentos, Escola de Engenharia Mauá, Instituto Mauá \\ de Tecnologia (IMT), Praça Mauá 1, CEP: 09.580-900, São Caetano do Sul - SP, Brasil. \\ E-mail: rodrigues@maua.br
}

(Submitted: May 7, 2013 ; Revised: August 26, 2013 ; Accepted: September 18, 2013)

\begin{abstract}
An anaerobic sequencing batch biofilm reactor (AnSBBR) containing immobilized biomass and operating with recirculation of the liquid phase (total liquid volume $4.5 \mathrm{~L}$; treated volume per cycle $1.9 \mathrm{~L}$ ) was used to treat sucrose-based wastewater at $30{ }^{\circ} \mathrm{C}$ and produce biohydrogen. The influence of applied volumetric organic load was studied by varying the influent concentration at 3600 and $5400 \mathrm{mgCOD} . \mathrm{L}^{-1}$ and using cycle lengths of 4, 3 and 2 hours, obtaining in this manner volumetric organic loads of $9,12,13.5,18$ and $27 \mathrm{gCOD} . \mathrm{L}^{-1} \cdot \mathrm{d}^{-1}$. Different performance indicators were used: productivity and yield of biohydrogen per applied and removed load, reactor stability and efficiency based on the applied and removed organic loads, both in terms of organic matter (measured as COD) and carbohydrate (sucrose). The results revealed system stability $(32-37 \%$ of $\mathrm{H}_{2}$ in biogas) during biohydrogen production, as well as substrate consumption (12-19\% COD; $97-99 \%$ sucrose). Conversion efficiencies decreased when the influent concentration was increased (at constant cycle length) and when cycle lengths were reduced (at constant influent concentrations). The best yield was 4.16 mol$\mathrm{H}_{2} \cdot \mathrm{kg}-\mathrm{SUC}^{-1}$ (sucrose load) at $9 \mathrm{gCOD} \cdot \mathrm{L}^{-1} \cdot \mathrm{d}^{-1}$ (3600 mgCOD.L $\mathrm{L}^{-1}$ and $4 \mathrm{~h}$ ) with $\mathrm{H}_{2}$ content in the biogas of $36 \%$ $\left(64 \% \mathrm{CO}_{2}\right.$ and $\left.0 \% \mathrm{CH}_{4}\right)$. However, the best specific molar productivity of hydrogen was $8.5 \mathrm{molH}_{2} \cdot \mathrm{kgTVS}^{-1} \cdot \mathrm{d}^{-1}$ $\left(32 \% \mathrm{H}_{2} ; 68 \% \mathrm{CO}_{2} ; 0 \% \mathrm{CH}_{4}\right)$, at $18 \mathrm{gCOD} \cdot \mathrm{L}^{-1} \cdot \mathrm{d}^{-1}\left(5400 \mathrm{mgCOD} \cdot \mathrm{L}^{-1}\right.$ and $\left.3 \mathrm{~h}\right)$, indicating that the best productivity tends to occur at higher organic loads, as this parameter involves the "biochemical generation" of biogas, whereas the best yield tends to occur at lower and/or intermediate organic loads, as this parameter involves "biochemical consumption" of the substrate. The most significant metabolites were ethanol, acetic acid and butyric acid. Microbiological analyses revealed that the biomass contained bacilli and endospore filaments and showed no significant variations in morphology between different experimental conditions.
\end{abstract}

Keywords: AnSBBR; Biohydrogen; Liquid circulation; Organic loading; Influent concentration; Cycle length.

\section{INTRODUCTION}

Concerns regarding the use of fossil fuels, together with environmental issues, have led scientists to search for new energy alternatives. There are several ways to produce energy via biological means: methane from anaerobic digestion, ethanol obtained from fermentation, and hydrogen obtained by fermentation

*To whom correspondence should be addressed 
of several substrates. Within this perspective, hydrogen has appeared as a promising substitute for petroleum-derived fuels. The advantages of this fuel include clean combustion and high energy potential. At present, studies are focused on finding new ways for large scale production to make production economically feasible (Lin and Lay, 2005; Argun et al., 2008; Turcot et al., 2008; Wang et al., 2008 and 2009a).

Hydrogen production from waste may become a technological and economically feasible alternative and, at the same time, integrate the principles of sustainable development because different residues can be used as substrate for biohydrogen production, such as: sucrose, wheat starch, organic fraction of solid waste, biological reactor effluent, vegetable oils and waste from biodiesel and ethanol production processes (Lin and Lay, 2005; Argun et al., 2008; Turcot et al., 2008, Wang et al., 2008 and 2009a; Das and Veziroglu, 2001; Kawagoshi et al. 2005; Li and Fang, 2007; Davila-Vazquez et al., 2007; Ren et al., 2008; Wang et al., 2009b). Moreover, the effluent of biohydrogen production units may be used to produce biomethane by anaerobic digestion.

These residues are used in studies that assess hydrogen productivity and operational stability of the reactors using operation parameters for hydrogen production including several factors, such as the nature of the inocula, $\mathrm{pH}$, temperature, nature and concentration of the substrate, and residence time of the liquid in the reactor. These parameters have specific influences on the productivity and yield per removed load (Tanisho and Ishiwata, 1995; Khanal et al., 2003; Wu et al., 2003; Lin and Lay, 2004a-b and 2005; Ferchichi et al., 2005; Ito et al., 2005; Zhang et al., 2006; Mu et al., 2006; Liu et al., 2006; Jeong et al., 2007; Nishio and Nakashimada, 2007; Mohan et al., 2007; Alzate-Gaviria et al., 2007; Leite et al., 2008; Yang et al., 2008; Argun et al., 2008; OThong et al., 2008; Oztekin et al., 2008; SabourinProvost et al., 2009; Wu et al., 2010; Buitrón and Carvajal, 2010; Sreethawong et al., 2010; Badiei et al., 2011; Mohanakrishna et al., 2011).

Anaerobic reactors operated in sequencing batch and/or fed batch seem to be appropriate for biohydrogen production. These reactors have a typical cycle that comprises four steps: (i) feeding, in which the fill time may vary, defining the feed strategy as batch and/or fed batch; (ii) the treatment itself, via biotransformation of the wastewater constituents by microorganisms; (iii) sedimentation, only when the biomass is in granular form (ASBR) since this step is not required when the biomass is immobilized on inert support (AnSBBR); and (iv) discharge, i.e., removal of treated and clarified liquid.

These reactors have been studied in several projects which focus on optimization of conventional bioreactors and on novel configurations that allow application of the system to different wastewaters, as well as full-scale implementation (Bagley and Brodkorb, 1999; Massé and Masse, 2000; Zaiat et al., 2001; Angenent et al., 2002; Shizas and Bagley, 2002; Rodrigues et al., 2003; Damasceno et al., 2008; Oliveira et al., 2008; Oliveira et al., 2009; Friedl et al., 2009; Michelan et al., 2009; Bezerra et al., 2009 and 2011; Mockaitis et al., 2010; Carvalhinha et al., 2010; Novaes et al., 2010a; Novaes et al., 2010b; Selma et al., 2010; Oliveira et al., 2010; Cubas et al., 2011; Rodrigues et al., 2011). Furthermore, these reactors have shown an increasing potential to generate biomethane (Bezerra et al., 2011; Lovato et al., 2012; Silva et al., 2013) and biohydrogen from wastewaters, i.e., wastewater can be used as raw material to obtain energy.

In this context, the main objective of this work was to assess the stability and performance of an anaerobic sequencing batch biofilm reactor (AnSBBR), with recirculation of the liquid phase and containing immobilized biomass, for biohydrogen production, treating sucrose-based synthetic wastewater. Reactor performance was assessed by means of yield and productivity indicators for different applied volumetric organic loads, obtained by modifying the influent concentration and cycle length, also taking into account the composition of the produced biogas (hydrogen, methane and carbon dioxide), the distribution of metabolites in the liquid effluent (volatile acids and ethanol) and substrate removal.

The justification for using the particular bioreactor and experimental protocol was to investigate discontinuous operation, which presents simple operational control for biogas generation and separation in "small scale" production units as an alternative to the continuous mode, taking into account flexibility in the feeding strategy (different flow rates and cycle length) and the possibility to use different influent wastewater concentrations available for treatment. Furthermore, some potential limitations of this reactor due to inherent transient behavior in batch operation were studied, such as the possibility of over-load (resulting in microbial inhibition) and lower productivity due to sequencing charge-discharge operations. Sucrose-based synthetic wastewater (favorable biodegradation characteristics) was used to focus the study on engineering the operating aspects of biohydrogen production. 


\section{MATERIALS AND METHODS}

\section{AnSBBR with Liquid Phase Circulation}

Figure 1 illustrates the scheme of the system used for biohydrogen production by anaerobic treatment of sucrose-based synthetic effluent. The reactor consisted of a cylindrical acrylic column with height of $540 \mathrm{~mm}$, external diameter of $100 \mathrm{~mm}$ and wall thickness of $3.5 \mathrm{~mm}$. A $30 \mathrm{~mm}$ compartment at the bottom of the reactor allowed enhanced distribution of the wastewater, preventing formation of preferential routes. At the upper part of the reactor a $30 \mathrm{~mm}$ region $(200 \mathrm{~mL})$ functioned as a biogas collector $\left(\mathrm{H}_{2}, \mathrm{CH}_{4}\right.$ and $\left.\mathrm{CO}_{2}\right)$. Hence, the total volume of the reactor was $4.3 \mathrm{~L}$ (empty volume).

The inert support containing the immobilized biomass was placed between perforated stainless steel plates, lined with screens on the upper side. These plates divided the $540 \mathrm{~mm}$ high reactor into five parts to avoid bed compacting and passage of the support particles between stages.

The recirculation unit comprised (i) a side reservoir, with a volume of $2.9 \mathrm{~L}$ (empty volume), consisting of a cylindrical acrylic container with height of $430 \mathrm{~mm}$, external diameter of $100 \mathrm{~mm}$ and wall thickness of $3.5 \mathrm{~mm}$; and (ii) an MCP Ismatec peristaltic pump with adjustable flow rate of up to 52.3 L.h $^{-1}$. A $100-\mathrm{mL}$ measuring cylinder was attached to the recirculation system for flow rate measurements. Hence, the total resulting volume of the reactor $(4.3 \mathrm{~L})$ and reservoir $(2.9 \mathrm{~L})$ was $7.2 \mathrm{~L}$.

Feeding and discharge were performed using
Prominent ${ }^{\circledR}$ diaphragm pumps, Beta/5 $\left(30 \mathrm{~L} \cdot \mathrm{h}^{-1}\right)$ and Concept/0223 (23 L.h $\left.{ }^{-1}\right)$, respectively, aided by an automation system consisting of RTST/20 Coel $^{\circledR}$ timers. A control unit was used for automate feeding, discharge and recirculation operations.

The reactor was placed in a chamber kept at $30 \pm$ $1{ }^{\circ} \mathrm{C}$, where the temperature was maintained constant by a system composed of sensor, controller (Novus ${ }^{\circledR}$, modelo N480), fan and electric resistance.

\section{Inert Support and Inoculum Immobilization}

The support used for biomass immobilization consisted of low-density polyethylene (LDPE) pellets obtained from recycled plastic waste, with length of $5 \mathrm{~mm}$ and diameter of $3 \mathrm{~mm}$. The bed formed with these LDPE particles had an apparent and real density of 470 and 825 g.L. $\mathrm{L}^{-1}$, respectively, and a porosity of $43 \%$.

The inoculum used in all experiments came from an up-flow anaerobic sludge blanket reactor (UASB) treating wastewater from a poultry slaughterhouse. This inoculum contained a diverse microbial consortium for acclimatization, according to the results of Kawagoshi et al. (2005).

The immobilization procedure consisted of immersing the LDPE pellets $(850 \mathrm{~g})$ for $1 \mathrm{~h}$ in $1 \mathrm{~L}$ of inoculum with total volatile solids (TVS) and total solids (TS) of 51 and 62 g.L. $\mathrm{L}^{-1}$, respectively, previously crushed through a sieve ( $2 \mathrm{~mm}$ mesh) to facilitate its retention/distribution throughout the reactor bed. The excess sludge was removed and the support material was introduced into the reactor.

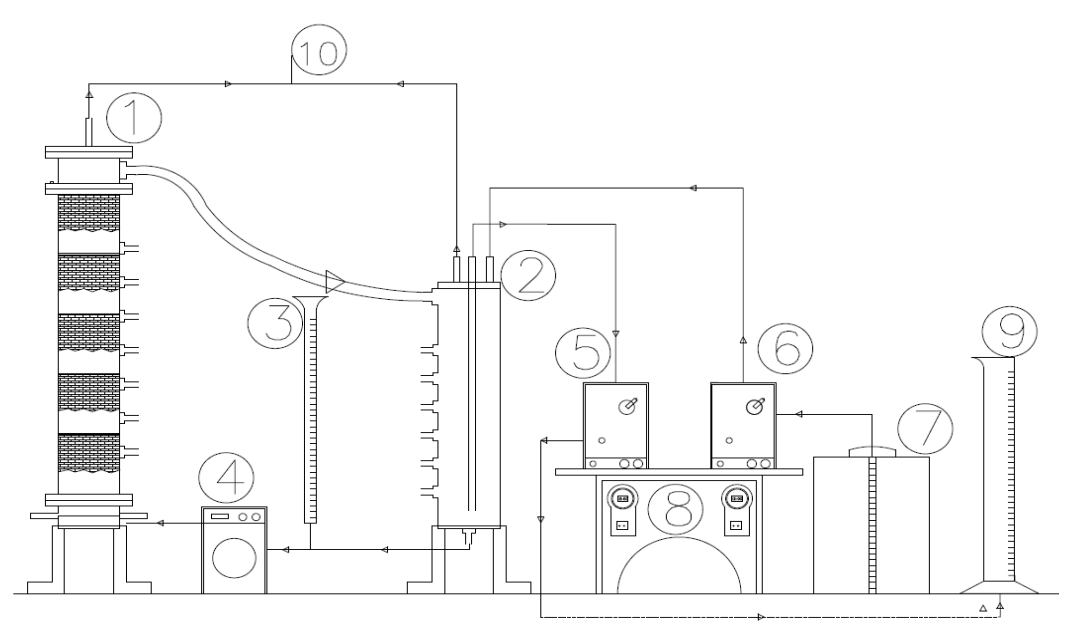

1) reactor containing immobilized biomass;

2) circulation reservoir;

3) flow rate meter;

4) circulation pump;

5) discharge pump;

6) feed pump;

7) wastewater reservoir;

8) control unit;

9) effluent measuring cylinder collector;

10) biogas outlet.

Figure 1: Scheme of the AnSBBR with liquid phase circulation. 


\section{Sucrose Based Synthetic Wastewater}

The composition (mg. $\mathrm{L}^{-1}$ ), based on $1000 \mathrm{mg}$ COD. $\mathrm{L}^{-1}$, of the synthetic wastewater used in the experiments was: sucrose $\left(\mathrm{C}_{12} \mathrm{O}_{22} \mathrm{O}_{11}\right)$ 893.0; urea $\left(\mathrm{CH}_{4} \mathrm{~N}_{2} \mathrm{O}\right)$ 5.80; nickel sulfate $\left(\mathrm{NiSO}_{4} \cdot 6 \mathrm{H}_{2} \mathrm{O}\right) 0.50$; ferrous sulfate $\left(\mathrm{FeSO}_{4} .7 \mathrm{H}_{2} \mathrm{O}\right)$ 2.50; ferric chloride $\left(\mathrm{FeCl}_{3} .6 \mathrm{H}_{2} \mathrm{O}\right)$ 0.25; calcium chloride $\left(\mathrm{CaCl}_{2} .2 \mathrm{H}_{2} \mathrm{O}\right)$ 2.06; cobalt chloride $\left(\mathrm{CoCl}_{2} .6 \mathrm{H}_{2} \mathrm{O}\right)$ 0.04; selenium dioxide $\left(\mathrm{SeO}_{2}\right)$ 0.04; monobasic potassium phosphate $\left(\mathrm{KH}_{2} \mathrm{PO}_{4}\right)$ 5.36; dibasic potassium phosphate $\left(\mathrm{K}_{2} \mathrm{HPO}_{4}\right) 1.30$; dibasic sodium phosphate $\left(\mathrm{Na}_{2} \mathrm{HPO}_{4}\right)$ 2.70; sodium bicarbonate $\left(\mathrm{NaHCO}_{3}\right)$ 250.0; initial $\mathrm{pH}$ adjusted with $12 \mathrm{M}$ hydrochloric acid.

The ratio of the carbon and nitrogen-urea source $(\mathrm{C} / \mathrm{N})$ was set at approximately 140 and $\mathrm{COD} / \mathrm{P}$ ratio at approximately 500 (1000:2) (Leite et al., 2008). Initial influent $\mathrm{pH}$ was adjusted so as to maintain the effluent $\mathrm{pH}$ near 5 . The $\mathrm{C} / \mathrm{N}$ ratio $(\mathrm{g}-\mathrm{C} / \mathrm{g}-\mathrm{N})$ was calculated according to the mass percentage of the elements carbon and nitrogen in sucrose (glucosefructose $-\mathrm{C}_{12} \mathrm{H}_{22} \mathrm{O}_{11}-144 \mathrm{~g}$-C/342g-sucrose) and urea $\left(\mathrm{CH}_{4} \mathrm{~N}_{2} \mathrm{O}-28 \mathrm{~g}-\mathrm{N} / 60 \mathrm{~g}\right.$-urea $)$, which were part of the medium, resulting in a $\mathrm{C} / \mathrm{N}$ ratio of $139.3 \mathrm{~g}-\mathrm{C} / \mathrm{g}-\mathrm{N}$ $(=893 / 5.8=(893 \cdot 144 / 342) /(5.8 \cdot 28 / 60)=376.0 / 2.7)$. The $\mathrm{C} / \mathrm{P}$ ratio (g-C/g-P) was calculated according to the mass percentage of the elements carbon and phosphorus in sucrose (glucose-fructose $-\mathrm{C}_{12} \mathrm{H}_{22} \mathrm{O}_{11}-$ $144 \mathrm{~g}-\mathrm{C} / 342 \mathrm{~g}$-sucrose) and phosphorus salts $\left(\mathrm{KH}_{2} \mathrm{PO}_{4}\right.$ - $31 \mathrm{~g}-\mathrm{P} / 136 \mathrm{~g}-\mathrm{KH}_{2} \mathrm{PO}_{4} ; \mathrm{K}_{2} \mathrm{HPO}_{4}-31 \mathrm{~g}-\mathrm{P} / 174 \mathrm{~g}-\mathrm{K}_{2} \mathrm{HP}$ $\mathrm{O}_{4} ; \mathrm{Na}_{2} \mathrm{HPO}_{4}-31 \mathrm{~g}-\mathrm{P} / 142 \mathrm{~g}-\mathrm{Na}_{2} \mathrm{HPO}_{4}$ ), which were part of the medium, resulting in $\mathrm{C} / \mathrm{P}$ ratios: (i) 184.3 g-C/g-P $[=(893 \cdot 144 / 342) /(5.36 \cdot 31 / 136+1.30 \cdot 31 / 174$ $+2.70 \cdot 31 / 142)=376.0 / 2.04]$ in terms of $\mathrm{C}$; and (ii) $490.2 \mathrm{~g}-\mathrm{COD} / \mathrm{g}-\mathrm{P}[=(1000) /(5.36 \cdot 31 / 136+1.30 \cdot 31 /$ $174+2.70 \cdot 31 / 142)=1000 / 2.04]$ in terms of COD.

\section{Physical-Chemical Analyses and Microbiological Tests}

Reactor monitoring was carried out by measuring influent and effluent samples, unfiltered $\left(\mathrm{C}_{\mathrm{CT}}\right)$ and filtered $\left(\mathrm{C}_{\mathrm{CF}}\right)$ organic matter concentration as chemical oxygen demand (COD) and by the Dubois method for determining unfiltered $\left(\mathrm{C}_{\mathrm{ST}}\right)$ and filtered $\left(\mathrm{C}_{\mathrm{SF}}\right)$ carbohydrates, bicarbonate alkalinity (BA), total volatile acids (TVA), total solids (TS), total volatile solids (TVS), total suspended solids (TSS), volatile suspended solids (VSS); $\mathrm{pH}$ and volume fed/discharged per cycle (Standard Methods for Examination of Water and Wastewater, 1995).

The intermediate compounds of the anaerobic metabolism (acetone, methanol, ethanol, n-butanol, acetic, propionic, butyric, isobutyric, valeric, isovaleric and caproic acid) were analyzed by an Agilent Technologies 7890 gas chromatograph equipped with a flame ionization detector (FID), automatic injection (head space), GC Sampler 80, and an HPInnowax column $(30 \mathrm{~m} \times 0.25 \mathrm{~mm} \times 0.25 \mu \mathrm{m})$. Carrier gas was hydrogen with flow rate of $1.56 \mathrm{~mL} \cdot \mathrm{min}^{-1}$. Injector temperature was $250{ }^{\circ} \mathrm{C}$, injection volume $400 \mu \mathrm{L}$ and split ratio 10 . Oven temperature was programmed as follows: from $35^{\circ} \mathrm{C}$ to $38^{\circ} \mathrm{C}$ at $2{ }^{\circ} \mathrm{C}$. $\min ^{-1}$, from $38^{\circ} \mathrm{C}$ to $75^{\circ} \mathrm{C}$ at $10^{\circ} \mathrm{C} \cdot \mathrm{min}^{-1}$, from $75^{\circ} \mathrm{C}$ to $120^{\circ} \mathrm{C}$ at $35^{\circ} \mathrm{C} \cdot \mathrm{min}^{-1}$, at $120^{\circ} \mathrm{C}$ for $1 \mathrm{~min}$, from $120^{\circ} \mathrm{C}$ to $170{ }^{\circ} \mathrm{C}$ at $10^{\circ} \mathrm{C} \cdot \mathrm{min}^{-1}$ and at $170{ }^{\circ} \mathrm{C}$ for $2 \mathrm{~min}$. Detector temperature was $280^{\circ} \mathrm{C}$ with hydrogen flow (fuel) of $30 \mathrm{~mL} \cdot \mathrm{min}^{-1}$, synthetic air flow (oxidant) of $300 \mathrm{~mL} \cdot \mathrm{min}^{-1}$ and make up (nitrogen) flow of 30 $\mathrm{mL} \cdot \mathrm{min}^{-1}$. The head space method was employed in these analyses, using as internal standard crotonic acid (for volatile acids determination) and isobutanol (for determination of acetone and alcohols).

Composition of the biogas generated via anaerobic degradation was analyzed by gas chromatography using an Agilent Technologies ${ }^{\circledR} 7890$ gas chromatograph equipped with thermal conductivity detector (TCD) and GS-Carbonplot column (30 $\mathrm{m} \times$ $0.53 \mathrm{~mm} \times 3.0 \mu \mathrm{m}$ ). The carrier gas used was argon at $3.67 \mathrm{~mL} \cdot \mathrm{min}^{-1}$, the injector temperature was $185^{\circ} \mathrm{C}$, injection volume $200 \mu \mathrm{L}$ and split ratio 10 . Oven temperature was programmed as follows: $40{ }^{\circ} \mathrm{C}$ isothermal for $5 \mathrm{~min}$. Detector temperature was $150^{\circ} \mathrm{C}$, with makeup (argon) flow rate of $8.33 \mathrm{~mL} \cdot \mathrm{min}^{-1}$.

Volumetric production was measured with a Ritter Milligacounter gas meter.

Quantification of the biomass inside the reactor was performed at every two experimental conditions to calculate the applied and removed specific organic load.

Microbiological tests were examined under glass slides by means of common optical and fluorescence phase contrast using an Olympus ${ }^{\circledR}$ BX-41-FL-III microscope with a 3.3 MPixel QCOLOR3C digital camera and IMAGE PRO-EXPRESS v. 5.1 image analyzer.

\section{Experimental Procedure}

Assays were performed using increasing volumetric organic loads, by varying the influent concentration: 3600 and $5200 \mathrm{mgCOD} . \mathrm{L}^{-1}$, and cycle length: 4 , 3 and 2 h, i.e., 6,8 and 12 daily cycles (Table 1). The number of samples used for monitoring was 20 for each experimental condition, over a 30-day testing period.

The total work volume of the reactor and reservoir $(4.3+2.9=7.2 \mathrm{~L})$ comprised a volume of $2.6 \mathrm{~L}$ 
of medium retained in the system, $1.9 \mathrm{~L}$ of medium treated per cycle (volume fed at the start of the cycle and discharged at the end of the cycle), $1.8 \mathrm{~L}$ of support material, and the remaining $0.9 \mathrm{~L}$ for biogas collection $(0.2 \mathrm{~L}$ at the top of the reactor and $0.7 \mathrm{~L}$ at the top of the reservoir).

Table 1: Summary of the investigated experimental conditions".

\begin{tabular}{|c|c|c|c|c|c|}
\hline Assay & $\begin{array}{c}\mathbf{C}_{\text {ST,I }} \\
\left(\mathrm{gSUC}^{-1}\right. \\
\left.\mathrm{L}^{-1}\right)\end{array}$ & $\begin{array}{c}\mathbf{C}_{\mathrm{CT}, \mathrm{I}} \\
(\mathrm{gCOD} . \\
\left.\mathbf{L}^{-1}\right)\end{array}$ & $\begin{array}{c}\mathbf{t}_{\mathrm{C}} \\
\text { (h) }\end{array}$ & $\begin{array}{c}\text { AVOL }_{S T} \\
\left(\text { gSUC. }^{-1} \cdot \mathbf{d}^{-1}\right) \\
\mathbf{L}^{-1}\end{array}$ & $\begin{array}{l}\text { AVOL }_{\text {CT }} \\
\left(\text { gCOD. }^{-1}\right. \\
\left.\mathbf{L}^{-1} \cdot \mathbf{d}^{-1}\right)\end{array}$ \\
\hline 1 & 3.2 & 3.55 & 4.0 & 8.1 & 9.0 \\
\hline 2 & 3.2 & 3.55 & 3.0 & 10.8 & 12.0 \\
\hline 3 & 4.8 & 5.33 & 4.0 & 12.2 & 13.5 \\
\hline 4 & 4.8 & 5.33 & 3.0 & 16.9 & 18.0 \\
\hline 5 & 3.2 & 3.55 & 2.0 & 16.2 & 18.0 \\
\hline 6 & 4.8 & 5.33 & 2.0 & 24.3 & 27.0 \\
\hline
\end{tabular}

$* \mathrm{~V}_{\mathrm{F}}=1.9 \pm 0.1 \mathrm{~L}$ and $\mathrm{V}_{\mathrm{R}}=4.5 \pm 0.1 \mathrm{~L}$.

Reactor operation (with inert support and inoculum) was performed as follows: in the first cycle $4.5 \mathrm{~L}$ of medium were fed to the system $(2.6 \mathrm{~L}$ of medium in the reactor and $1.9 \mathrm{~L}$ in the reservoir) for $20 \mathrm{~min}$ ). After the end of feeding the recirculation flow (20 L.h ${ }^{-1}$ - recirculation rate of $0.2 \mathrm{~cm} . \mathrm{s}^{-1}$ ) was turned on. At the end of the cycle, of which the duration was a function of the experimental conditions, recirculation was switched off and $1.9 \mathrm{~L}$ of medium was discharged in $10 \mathrm{~min}$, with $2.6 \mathrm{~L}$ residual volume held in the reactor (besides the $1.8 \mathrm{~L}$ inert support). Immediately after this discharge, a new cycle started, in which $1.9 \mathrm{~L}$ of medium was fed in $10 \mathrm{~min}$, and recirculation was turned on. At the end of the cycle, recirculation was stopped and then discharge started, which lasted $10 \mathrm{~min}$. Thus, the cycles were repeated, characterizing the sequencing batch operation.

After reaching stability, verified by the attainment of approximately constant values for the monitored effluent parameters at the end of the cycles, profiles of the following were obtained: filtered organic matter concentrations, total carbohydrates, bicarbonate alkalinity, total volatile acids, intermediate metabolites (acetone, acids and alcohols), $\mathrm{pH}$ and biogas (composition and production). To obtain the aforementioned profiles, samples were taken at 30-min time intervals during a cycle. The volume collected did not exceed $240 \mathrm{~mL}$, being always $8 \%$ below the total volume of wastewater in the reactor. After each operation, sludge samples were taken from the reactor for microbiological analysis.

The experimental results obtained from the system monitoring and from the profiles at each operating condition were analyzed considering the effect of the investigated variables on process stability and performance, as well as the different hydrogen production indicators. The microbiological analyses allowed assessment of microbial morphology.

\section{Theoretical}

The organic matter removal efficiencies for unfiltered $\left(\varepsilon_{\mathrm{CT}}\right)$ and filtered $\left(\varepsilon_{\mathrm{CF}}\right)$ samples were calculated by Equation (1), in which $\mathrm{C}_{\mathrm{CT}, \mathrm{I}}$ is the concentration of total organic matter (COD) in the influent, $\mathrm{C}_{\mathrm{CT}}$ and $\mathrm{C}_{\mathrm{CF}}$ are organic matter concentrations for unfiltered and filtered samples in the effluent, respectively.

$$
\begin{aligned}
& \varepsilon_{\mathrm{CT}}(\%)=\frac{\mathrm{C}_{\mathrm{CT}, \mathrm{I}}-\mathrm{C}_{\mathrm{CT}}}{\mathrm{C}_{\mathrm{CT}, \mathrm{I}}} \cdot 100 \\
& \varepsilon_{\mathrm{CF}}(\%)=\frac{\mathrm{C}_{\mathrm{CT}, \mathrm{I}}-\mathrm{C}_{\mathrm{CF}}}{\mathrm{C}_{\mathrm{CT}, \mathrm{I}}} \cdot 100
\end{aligned}
$$

The organic matter removal efficiencies based on carbohydrates (sucrose) for unfiltered $\left(\varepsilon_{\mathrm{ST}}-\mathrm{C}_{\mathrm{ST}, \mathrm{I}}\right.$ and $\left.\mathrm{C}_{\mathrm{ST}}\right)$ and filtered $\left(\varepsilon_{\mathrm{SF}}-\mathrm{C}_{\mathrm{ST}, \mathrm{I}}\right.$ and $\left.\mathrm{C}_{\mathrm{SF}}\right)$ samples were calculated in a similar way (Equation (2)).

$$
\begin{aligned}
& \varepsilon_{\mathrm{ST}}(\%)=\frac{\mathrm{C}_{\mathrm{ST}, \mathrm{I}}-\mathrm{C}_{\mathrm{ST}}}{\mathrm{C}_{\mathrm{ST}, \mathrm{I}}} \cdot 100 \\
& \varepsilon_{\mathrm{SF}}(\%)=\frac{\mathrm{C}_{\mathrm{ST}, \mathrm{I}}-\mathrm{C}_{\mathrm{SF}}}{\mathrm{C}_{\mathrm{ST}, \mathrm{I}}} \cdot 100
\end{aligned}
$$

Equation (3) was used to calculate the applied volumetric organic load $\left(\mathrm{AVOL}_{\mathrm{ST}}\right.$ or $\left.\mathrm{AVOL}_{\mathrm{CT}}\right)$, expressed as $\mathrm{kgSUC} \cdot \mathrm{m}^{-3} \cdot \mathrm{d}^{-1}$ or $\mathrm{kgCOD} \cdot \mathrm{m}^{-3} \cdot \mathrm{d}^{-1}$, respectively, defined as the amount of carbohydrate (sucrose) or organic matter (measured as COD) applied to the reactor per unit time and per reactor medium volume, where $V_{F}$ is the volume of wastewater fed in the cycle, $N$ is the number of cycles per day and $V_{R}$ is the volume of liquid medium in the reactor.

$$
\begin{aligned}
& \operatorname{AVOL}_{S T}=\frac{\left(V_{F} \cdot N\right) \cdot C_{S T, I}}{V_{R}} \\
& \operatorname{AVOL}_{C T}=\frac{\left(V_{F} \cdot N\right) \cdot C_{C T, I}}{V_{R}}
\end{aligned}
$$

Equation (4) was used to calculate the applied specific organic load $\left(\mathrm{ASOL}_{\mathrm{ST}}\right.$ or $\left.\mathrm{ASOL}_{\mathrm{CT}}\right)$, expressed as $\mathrm{kgSUC} \cdot \mathrm{gTVS}^{-1} \cdot \mathrm{d}^{-1}$ or $\mathrm{kgCOD} \cdot \mathrm{m}^{-3} \cdot \mathrm{d}^{-1}$, re- 
spectively, defined as the amount of carbohydrate (sucrose) or organic matter (COD) applied to the reactor per unit time and per mass of total volatile solids in the reactor, where $\mathrm{M}_{\mathrm{TVS}}$ is the mass of total volatile solids in the reactor.

$$
\begin{aligned}
& \operatorname{ASOL}_{\mathrm{ST}}=\frac{\left(\mathrm{V}_{\mathrm{F}} \cdot \mathrm{N}\right) \cdot \mathrm{C}_{\mathrm{ST}, \mathrm{I}}}{\mathrm{M}_{\mathrm{TVS}}} \\
& \operatorname{ASOL}_{\mathrm{CT}}=\frac{\left(\mathrm{V}_{\mathrm{F}} \cdot \mathrm{N}\right) \cdot \mathrm{C}_{\mathrm{CT}, \mathrm{I}}}{\mathrm{M}_{\mathrm{TVS}}}
\end{aligned}
$$

The removed volumetric organic load $\left(\mathrm{RVOL}_{\mathrm{SF}}\right.$ or $\mathrm{RVOL}_{\mathrm{CF}}$ ), expressed as $\mathrm{kgSUC} \cdot \mathrm{m}^{-3} \cdot \mathrm{d}^{-1}$ or $\mathrm{kgCOD}$. $\mathrm{m}^{-3} \cdot \mathrm{d}^{-1}$, respectively, for filtered samples, defined as the amount of carbohydrate (sucrose) or organic matter (measured as COD) removed by the reactor per unit time and per reactor medium volume, was calculated by Equation (5).

$$
\begin{gathered}
\operatorname{RVOL}_{\mathrm{SF}}=\frac{\left(\mathrm{V}_{\mathrm{F}} \cdot \mathrm{N}\right) \cdot\left(\mathrm{C}_{\mathrm{ST}, \mathrm{I}}-\mathrm{C}_{\mathrm{SF}}\right)}{\mathrm{V}_{\mathrm{R}}} \\
\operatorname{RVOL}_{\mathrm{CF}}=\frac{\left(\mathrm{V}_{\mathrm{F}} \cdot \mathrm{N}\right) \cdot\left(\mathrm{C}_{\mathrm{CT}, \mathrm{I}}-\mathrm{C}_{\mathrm{CF}}\right)}{\mathrm{V}_{\mathrm{R}}}
\end{gathered}
$$

The removed specific organic load $\left(\mathrm{RSOL}_{\mathrm{SF}}\right.$ or $\mathrm{RSOL}_{\mathrm{CF}}$ ), expressed as $\mathrm{kgSUC} . \mathrm{gTVS}^{-1} \cdot \mathrm{d}^{-1}$ or $\mathrm{kgCOD} . \mathrm{gTVS}^{-1} \cdot \mathrm{d}^{-1}$, respectively, for filtered samples, defined as the amount of carbohydrate (sucrose) or organic matter (measured as COD) removed by the reactor per unit time and per mass of total volatile solids in the reactor, was calculated by Equation (6).

$$
\begin{aligned}
& \operatorname{RSOL}_{\mathrm{SF}}=\frac{\left(\mathrm{V}_{\mathrm{F}} \cdot \mathrm{N}\right) \cdot\left(\mathrm{C}_{\mathrm{ST}, \mathrm{I}}-\mathrm{C}_{\mathrm{SF}}\right)}{\mathrm{M}_{\mathrm{TVS}}} \\
& \mathrm{RSOL}_{\mathrm{CF}}=\frac{\left(\mathrm{V}_{\mathrm{F}} \cdot \mathrm{N}\right) \cdot\left(\mathrm{C}_{\mathrm{CT}, \mathrm{I}}-\mathrm{C}_{\mathrm{CF}}\right)}{\mathrm{M}_{\mathrm{TVS}}}
\end{aligned}
$$

Equation (7) was used to calculate the molar productivity (MPr), expressed as $\mathrm{molH}_{2} \cdot \mathrm{m}^{-3} \cdot \mathrm{d}^{-1}$, defined by the ratio between hydrogen produced per unit time $\left(\mathrm{n}_{\mathrm{H}_{2}}\right)$ and the volume of liquid medium in the reactor $\left(V_{R}\right)$, where $n_{H_{2}}$ is the number of moles of hydrogen produced during the cycle. Equation (8) was used to calculate the specific molar productivity (SMPr), expressed as $\mathrm{molH}_{2} \cdot \mathrm{kgTVS}^{-1} \cdot \mathrm{d}^{-1}$, defined by the ratio between hydrogen produced per unit time
$\left(\mathrm{n}_{\mathrm{H}_{2}}\right)$ and the mass of total volatile solids inside the reactor $\left(\mathrm{M}_{\mathrm{TVS}}\right)$.

$\operatorname{MPr}=\frac{\mathrm{N} \cdot \mathrm{n}_{\mathrm{H}_{2}}}{\mathrm{~V}_{\mathrm{R}}}$

$\mathrm{SMPr}=\frac{\mathrm{N} \cdot \mathrm{n}_{\mathrm{H}_{2}}}{\mathrm{M}_{\mathrm{TVS}}}$

The molar yield per applied load MYAL $_{\mathrm{S}, \mathrm{m}}$ or $\mathrm{MYAL}_{\mathrm{C}, \mathrm{m}}$ ), expressed as $\mathrm{molH}_{2} \cdot \mathrm{kgSUC}^{-1}$ or $\mathrm{molH}_{2} \cdot \mathrm{kgCOD}^{-1}$, respectively, for unfiltered samples, defined by the relation between the hydrogen produced per unit time $\left(\mathrm{n}_{\mathrm{H}_{2}}\right)$ and the applied organic matter based on carbohydrate (sucrose) or organic matter (measured as COD), was calculated by Equation (9).

$$
\begin{aligned}
& \text { MYAL }_{\mathrm{S}, \mathrm{m}}=\frac{\mathrm{n}_{\mathrm{H}_{2}}}{\mathrm{~N} \cdot \mathrm{V}_{\mathrm{F}} \cdot \mathrm{C}_{\mathrm{ST}, \mathrm{I}}} \\
& \text { MYAL }_{\mathrm{C}, \mathrm{m}}=\frac{\mathrm{n}_{\mathrm{H}_{2}}}{\mathrm{~N} \cdot \mathrm{V}_{\mathrm{F}} \cdot \mathrm{C}_{\mathrm{CT}, \mathrm{I}}}
\end{aligned}
$$

The molar yield per removed load MYRL $_{\mathrm{S}, \mathrm{m}}$ or $\mathrm{MYRL}_{\mathrm{C}, \mathrm{m}}$ ), expressed as $\mathrm{molH}_{2} \cdot \mathrm{kgSUC}^{-1}$ or $\mathrm{molH}_{2} \cdot \mathrm{kgCOD}^{-1}$, respectively, for filtered samples, defined by the relation between the hydrogen produced per unit time $\left(\mathrm{n}_{\mathrm{H}_{2}}\right)$ and the applied organic matter based on carbohydrate (sucrose) or organic matter (measured as COD), was calculated by Equation (10).

$$
\begin{aligned}
& \text { MYRL }_{\mathrm{s}, \mathrm{m}}=\frac{\mathrm{n}_{\mathrm{H}_{2}}}{\mathrm{~N} \cdot \mathrm{V}_{\mathrm{F}} \cdot\left(\mathrm{C}_{\mathrm{ST}, \mathrm{I}}-\mathrm{C}_{\mathrm{SF}}\right)} \\
& \text { MYRL }_{\mathrm{C}, \mathrm{m}}=\frac{\mathrm{n}_{\mathrm{H}_{2}}}{\mathrm{~N} \cdot \mathrm{V}_{\mathrm{F}} \cdot\left(\mathrm{C}_{\mathrm{CT}, \mathrm{I}}-\mathrm{C}_{\mathrm{CF}}\right)}
\end{aligned}
$$

\section{RESULTS AND DISCUSSION}

The variation in reactor performance is shown in Tables 2 to 4 which can be analyzed by considering three parameters: the increase in applied organic load (conditions 1/2/3/4/5/6) and the variation in the two parameters intrinsic to the organic load: the cycle length (conditions $1 / 2 / 5$ and 3/4/6 - same influent concentration) and influent concentration $(1 / 3,2 / 4$ and 
$5 / 6$ - same cycle length). In the biogas samples only hydrogen and carbon dioxide were detected, i.e., no methane was detected under the experimental conditions (detection limit of $0.01 \mathrm{mmol} . \mathrm{L}^{-1}$ ).

The average value of total volatile solids in the bed $\left(\mathrm{M}_{\mathrm{TVS}}\right)$ was $23 \pm 2 \mathrm{gTVS}$ and of support material $\left(\mathrm{M}_{\text {Support }}\right)$ was 1536 g-support, resulting in specific $\left(\mathrm{C}_{\mathrm{X} \text {-TVS }}\right)$ and volumetric $\left(\mathrm{C}_{\mathrm{X}-\mathrm{TVS}}\right)$ biomass concentration of $0.015 \pm 0.002$ gTVS.gsupport $^{-1}$ and $5.1 \pm 0.3$ gTVS.L ${ }^{-1}$, respectively, for a volume fed per cycle $\left(\mathrm{V}_{\mathrm{F}}\right)$ of $1.9 \pm 0.1 \mathrm{~L}$ and total liquid medium in the reactor $\left(\mathrm{V}_{\mathrm{R}}\right)$ of $4.5 \pm 0.1 \mathrm{~L}$.

The biomass inside the reactor presented endospores under all conditions and no significant differences in biomass between conditions was detected. The presence of endospores and the presence of metabolites in the effluent such as ethanol, acetic acid and butyric acid, accompanied by the production of hydrogen gas indicate fermentation bybacteria of the genus Clostridium (Lin et al, 2007).

\section{Organic Matter (COD and Carbohydrate) Removal}

The results obtained for the six different experimental conditions contained in Table 2 showed that the average removal efficiency of organic matter (COD) for filtered samples was $18 \%$ while stability was maintained throughout the experimental phase. It can be observed that different applied volumetric organic loads from the different cycle lengths (with the same influent concentration) and different influent concentrations (with the same cycle length) did not affect COD removal, since the organic matter was converted into intermediates, resulting in reduced COD removal under all conditions.

The behavior of influent and effluent carbohydrate (sucrose) concentration under all conditions showed that nearly all sucrose introduced into the reactor was consumed, giving rise to intermediate acids and alcohols resultant from acidogenesis. Average carbohydrate conversion efficiency during the experimental period was $98 \%$, which demonstrates efficient and stable acidogenesis throughout the experimental phase. The high organic loads from conditions 5 and 6 caused a slight reduction in carbohydrate conversion efficiency from $99 \%$ to $95 \%$ and $94 \%$, respectively.

Thus, under all experimental conditions the carbohydrate conversion efficiency remained high and approximately constant and was not significantly influenced by the applied organic load (which was different depending on cycle length and influent concentration). The results obtained in this work $\left(\mathrm{AVOL}_{\mathrm{C}}\right.$ of $\left.8.2-26.6 \mathrm{kgCOD} \cdot \mathrm{m}^{-3} \cdot \mathrm{d}^{-1}\right)$ may be com- pared with Cheong et al. (2006), Vijaya Bhaskar et al. (2008), Chen et al. (2009) and Sreethawong et al. (2010) who used an ASBR treating a synthetic substrate (glucose or sucrose) to produce biohydrogen with $\mathrm{AVOL}_{\mathrm{C}}$ of $32-128,6.3-7.9,22.1$ and $10-56$ $\mathrm{kgCOD} \cdot \mathrm{m}^{-3} \cdot \mathrm{d}^{-1}$, respectively.

Table 2: Values of the monitored variables in conditions 1 to 6.

\begin{tabular}{|c|c|c|c|}
\hline \multicolumn{2}{|c|}{ Parameter } & Influent & Effluent \\
\hline \multicolumn{4}{|c|}{ condition $1\left(3550 \mathrm{mgCOD} . \mathrm{L}^{-1}-4 \mathrm{~h}\right)$} \\
\hline $\mathrm{C}_{\mathrm{CT}}$ & {$\left[\mathrm{mgCOD} \cdot \mathrm{L}^{-1}\right]$} & $3671 \pm 149$ & $3067 \pm 136$ \\
\hline $\mathrm{C}_{\mathrm{CF}}$ & {$\left[\mathrm{mgCOD} \cdot \mathrm{L}^{-1}\right]$} & - & $2985 \pm 223$ \\
\hline$\varepsilon_{\mathrm{CT}}$ & {$[\%]$} & - & $16 \pm 4$ \\
\hline$\varepsilon_{\mathrm{CF}}$ & {$[\%]$} & - & $19 \pm 6$ \\
\hline $\mathrm{C}_{\mathrm{ST}}$ & {$\left[\mathrm{mgSUC} . \mathrm{L}^{-1}\right]$} & $3230 \pm 129$ & $59 \pm 21$ \\
\hline $\mathrm{C}_{\mathrm{SF}}$ & {$\left[\mathrm{mgSUC} \cdot \mathrm{L}^{-1}\right]$} & - & $39 \pm 11$ \\
\hline$\varepsilon_{\mathrm{ST}}$ & {$[\%]$} & - & $98 \pm 1$ \\
\hline$\varepsilon_{\mathrm{SF}}$ & {$[\%]$} & - & $99 \pm 1$ \\
\hline TVA & {$\left[\mathrm{mgHAc} . \mathrm{L}^{-1}\right]$} & $25 \pm 85$ & $660 \pm 89$ \\
\hline BA & {$\left[\mathrm{mgCaCO}_{3} \cdot \mathrm{L}^{-1}\right]$} & $357 \pm 50$ & $173 \pm 83$ \\
\hline $\mathrm{pH}$ & {$[\mathrm{u}]$} & $6.4 \pm 0.1$ & $4.7 \pm 0.2$ \\
\hline \multicolumn{4}{|c|}{ condition $2\left(3550\right.$ mgCOD. $\left.^{-1}-3 \mathrm{~h}\right)$} \\
\hline $\mathrm{C}_{\mathrm{CT}}$ & {$\left[\mathrm{mgCOD} \cdot \mathrm{L}^{-1}\right]$} & $3673 \pm 149$ & $3216 \pm 190$ \\
\hline $\mathrm{C}_{\mathrm{CF}}$ & {$\left[\mathrm{mgCOD} . \mathrm{L}^{-1}\right]$} & - & $3152 \pm 151$ \\
\hline$\varepsilon_{\mathrm{CT}}$ & {$[\%]$} & - & $12 \pm 5$ \\
\hline$\varepsilon_{\mathrm{CF}}$ & {$[\%]$} & - & $14 \pm 4$ \\
\hline $\mathrm{C}_{\mathrm{ST}}$ & {$\left[\mathrm{mgSUC} \cdot \mathrm{L}^{-1}\right]$} & $3182 \pm 102$ & $69 \pm 27$ \\
\hline $\mathrm{C}_{\mathrm{SF}}$ & {$\left[\mathrm{mgSUC} . \mathrm{L}^{-1}\right]$} & - & $32 \pm 4$ \\
\hline$\varepsilon_{\mathrm{ST}}$ & {$[\%]$} & - & $98 \pm 1$ \\
\hline$\varepsilon_{\mathrm{SF}}$ & {$[\%]$} & - & $99 \pm 1$ \\
\hline TVA & {$\left[\mathrm{mgHAc} . \mathrm{L}^{-1}\right]$} & $26 \pm 6$ & $707 \pm 102$ \\
\hline $\mathrm{BA}$ & {$\left[\mathrm{mgCaCO}_{3} \cdot \mathrm{L}^{-1}\right]$} & $549 \pm 55$ & $316 \pm 50$ \\
\hline $\mathrm{pH}$ & {$[\mathrm{u}]$} & $7.3 \pm 0.1$ & $5.0 \pm 0.1$ \\
\hline \multicolumn{4}{|c|}{ condition $3\left(5330\right.$ mgCOD.L $\left.{ }^{-1}-4 h\right)$} \\
\hline $\mathrm{C}_{\mathrm{CT}}$ & {$\left[\mathrm{mgCOD} \cdot \mathrm{L}^{-1}\right]$} & $5448 \pm 392$ & $4653 \pm 183$ \\
\hline $\mathrm{C}_{\mathrm{CF}}$ & {$\left[\mathrm{mgCOD} . \mathrm{L}^{-1}\right]$} & - & $4442 \pm 183$ \\
\hline$\varepsilon_{\mathrm{CT}}$ & {$[\%]$} & - & $15 \pm 3$ \\
\hline$\varepsilon_{\mathrm{CF}}$ & {$[\%]$} & - & $18 \pm 3$ \\
\hline $\mathrm{C}_{\mathrm{ST}}$ & {$\left[\mathrm{mgSUC} . \mathrm{L}^{-1}\right]$} & $5043 \pm 513$ & $144 \pm 52$ \\
\hline $\mathrm{C}_{\mathrm{SF}}$ & {$\left[\mathrm{mgSUC} \cdot \mathrm{L}^{-1}\right]$} & - & $60 \pm 39$ \\
\hline$\varepsilon_{\mathrm{ST}}$ & {$[\%]$} & - & $97 \pm 1$ \\
\hline$\varepsilon_{\mathrm{SF}}$ & {$[\%]$} & - & $99 \pm 1$ \\
\hline TVA & {$\left[\mathrm{mgHAc} . \mathrm{L}^{-1}\right]$} & $29 \pm 8$ & $1034 \pm 148$ \\
\hline BA & {$\left[\mathrm{mgCaCO}_{3} \cdot \mathrm{L}^{-1}\right]$} & $784 \pm 63$ & $452 \pm 74$ \\
\hline $\mathrm{pH}$ & {$[\mathrm{u}]$} & $7.4 \pm 0.1$ & $4.9 \pm 0.1$ \\
\hline \multicolumn{4}{|c|}{ condition $4\left(5330 \mathrm{mgCOD}^{-1}-3 \mathrm{~h}\right)$} \\
\hline $\mathrm{C}_{\mathrm{CT}}$ & {$\left[\mathrm{mgCOD} . \mathrm{L}^{-1}\right]$} & $5064 \pm 465$ & $4406 \pm 364$ \\
\hline $\mathrm{C}_{\mathrm{CF}}$ & {$\left[\mathrm{mgCOD} \cdot \mathrm{L}^{-1}\right]$} & - & $3995 \pm 292$ \\
\hline$\varepsilon_{\mathrm{CT}}$ & {$[\%]$} & - & $13 \pm 5$ \\
\hline$\varepsilon_{\mathrm{CF}}$ & [\%] & - & $20 \pm 5$ \\
\hline $\mathrm{C}_{\mathrm{ST}}$ & {$\left[\mathrm{mgSUC} . \mathrm{L}^{-1}\right]$} & $4277 \pm 403$ & $125 \pm 13$ \\
\hline $\mathrm{C}_{\mathrm{SF}}$ & [mgSUC.L $\left.{ }^{-1}\right]$ & - & $42 \pm 10$ \\
\hline$\varepsilon_{\mathrm{ST}}$ & {$[\%]$} & - & $97 \pm 2$ \\
\hline$\varepsilon_{\mathrm{SF}}$ & {$[\%]$} & - & $99 \pm 2$ \\
\hline TVA & {$\left[\mathrm{mgHAc} . \mathrm{L}^{-1}\right]$} & $45 \pm 20$ & $1059 \pm 159$ \\
\hline $\mathrm{BA}$ & {$\left[\mathrm{mgCaCO}_{3} \cdot \mathrm{L}^{-1}\right]$} & $842 \pm 47$ & $465 \pm 32$ \\
\hline $\mathrm{pH}$ & {$[\mathrm{u}]$} & $7.4 \pm 0.1$ & $4.9 \pm 0.1$ \\
\hline
\end{tabular}

Continuation Table 2 


\section{Continuation Table 2}

Table 2: Values of the monitored variables in conditions 1 to 6 .

\begin{tabular}{|c|c|c|c|}
\hline \multicolumn{2}{|c|}{ Parameter } & Influent & Effluent \\
\hline \multicolumn{4}{|c|}{ condition $5\left(3550 \mathrm{mgCOD} . \mathrm{L}^{-1}-2 \mathrm{~h}\right)$} \\
\hline $\mathrm{C}_{\mathrm{CT}}$ & {$\left[\mathrm{mgCOD} \cdot \mathrm{L}^{-1}\right]$} & $3759 \pm 150$ & $3190 \pm 254$ \\
\hline $\mathrm{C}_{\mathrm{CF}}$ & {$\left[\mathrm{mgCOD} . \mathrm{L}^{-1}\right]$} & - & $3037 \pm 283$ \\
\hline$\varepsilon_{\mathrm{CT}}$ & {$[\%]$} & - & $15 \pm 7$ \\
\hline$\varepsilon_{\mathrm{CF}}$ & {$[\%]$} & - & $19 \pm 8$ \\
\hline $\mathrm{C}_{\mathrm{ST}}$ & {$\left[\mathrm{mgSUC} . \mathrm{L}^{-1}\right]$} & $3647 \pm 221$ & $252 \pm 172$ \\
\hline $\mathrm{C}_{\mathrm{SF}}$ & {$\left[\mathrm{mgSUC} . \mathrm{L}^{-1}\right]$} & - & $185 \pm 152$ \\
\hline$\varepsilon_{\mathrm{ST}}$ & {$[\%]$} & - & $93 \pm 5$ \\
\hline$\varepsilon_{\mathrm{SF}}$ & {$[\%]$} & - & $95 \pm 4$ \\
\hline TVA & {$\left[\mathrm{mgHAc} \cdot \mathrm{L}^{-1}\right]$} & $31 \pm 12$ & $678 \pm 88$ \\
\hline $\mathrm{AB}$ & {$\left[\mathrm{mgCaCO}_{3} \cdot \mathrm{L}^{-1}\right]$} & $570 \pm 33$ & $296 \pm 49$ \\
\hline $\mathrm{pH}$ & {$[\mathrm{u}]$} & $7.3 \pm 0.2$ & $5.0 \pm 0.2$ \\
\hline \multicolumn{4}{|c|}{ condition 6 (5330 mgCOD.L ${ }^{-1}-2$ h) } \\
\hline $\mathrm{C}_{\mathrm{CT}}$ & {$\left[\mathrm{mgCOD} \cdot \mathrm{L}^{-1}\right]$} & $5657 \pm 333$ & $4917 \pm 284$ \\
\hline $\mathrm{C}_{\mathrm{CF}}$ & {$\left[\mathrm{mgCOD} . \mathrm{L}^{-1}\right]$} & - & $4661 \pm 250$ \\
\hline$\varepsilon_{\mathrm{CT}}$ & {$[\%]$} & - & $12 \pm 5$ \\
\hline$\varepsilon_{\mathrm{CF}}$ & {$[\%]$} & - & $17 \pm 4$ \\
\hline $\mathrm{C}_{\mathrm{ST}}$ & {$\left[\mathrm{mgSUC} . \mathrm{L}^{-1}\right]$} & $5245 \pm 284$ & $398 \pm 282$ \\
\hline $\mathrm{C}_{\mathrm{SF}}$ & {$\left[\mathrm{mgSUC} . \mathrm{L}^{-1}\right]$} & - & $345 \pm 272$ \\
\hline$\varepsilon_{\mathrm{ST}}$ & {$[\%]$} & - & $93 \pm 5$ \\
\hline$\varepsilon_{\mathrm{SF}}$ & {$[\%]$} & - & $94 \pm 5$ \\
\hline TVA & {$\left[\mathrm{mgHAc} . \mathrm{L}^{-1}\right]$} & $28 \pm 6$ & $894 \pm 125$ \\
\hline $\mathrm{BA}$ & {$\left[\mathrm{mgCaCO}_{3} \cdot \mathrm{L}^{-1}\right]$} & $777 \pm 31$ & $328 \pm 58$ \\
\hline $\mathrm{pH}$ & {$[\mathrm{u}]$} & $7.3 \pm 0.1$ & $4.8 \pm 0.1$ \\
\hline
\end{tabular}

\section{Biogas ( $\mathrm{H}_{2}$ and $\mathrm{CO}_{2}$ with no $\left.\mathrm{CH}_{4}\right)$ Production}

Analysis of the biogas production (Table 3) shows that the increase in applied volumetric organic load, obtained by reducing cycle length at constant influent concentration (conditions $1 / 2 / 5$ and $3 / 4 / 6-50 \%$ reduction in cycle length), resulted in approximately the same value as conditions 1/2/5 (lower influent concentration) and increased biogas production for conditions 3/4/6 (higher influent concentration) (952/ $836 / 939$ and $1285 / 1489 / 1619$ NmL.cycle $^{-1}$ ). When the increase in applied organic volumetric load was due to the increase in influent concentration at constant cycle length (condition 1/3, 2/4 and 5/6 - 50\% increase in influent concentration), this also resulted in increased biogas production $(952 / 1285,836 / 1489$ and 939/1619 NmL.cycle ${ }^{-1}$ ), but with higher intensity, i.e., biogas production was more sensitive to influent concentration than to cycle length.

Comparing conditions 4/5 (1489/939 NmL.cycle ${ }^{-1}$ ), in which applied volumetric organic load is the same, but condition 5 was performed with lower influent concentration and cycle length in relation to condition 4 , there was increased biogas production in condition 4 , i.e., the reduction in cycle length with a proportional reduction in influent concentration (so as to maintain the same volumetric organic load) did not favor biogas production.

Analysis of biogas composition (Table 3) enabled identification of the fractions of each constituent and allowed correlation of these fractions with the volumes obtained; an average value of $37 \%$ was obtained for hydrogen, i.e., the applied volumetric load did not influence hydrogen content in the formed biogas. As a result, when the increase in applied volumetric organic load was due to the reduction in cycle length, maintaining influent concentration (conditions 1/2/4 and $3 / 4 / 6$ - 50\% reduction in cycle length), biohydrogen content also remained approximately constant (average of 36\% and standard deviation of $2 \%$ ). When the applied volumetric organic load increased due to increasing influent concentration at constant cycle length (condition 1/3, 2/4 and 5/6 - 50\% increase in influent concentration), biohydrogen content also remained approximately constant.

The main metabolites produced during operation (Table 3) were acetic acid, ethanol and butyric acid, produced in a similar manner during the entire operation. It can be observed that the major metabolite derived from the conversion of sucrose to produce biohydrogen was acetic acid.

\section{Hydrogen Productivity and Yield}

Table 4 contains the biohydrogen production indicators for all experimental conditions: applied/ removed and volumetric/specific organic load, molar production, volumetric/specific molar productivity and yield per applied/removed organic load. It can be inferred that biohydrogen production $\left(\mathrm{n}_{\mathrm{H} 2}\right)$ should not be used because the results indicate that the applied load does not systematically alter biohydrogen production. Such behavior can be attributed to the fact that the engineering factors involved in the different conditions were not included in this parameter.

In this context, biohydrogen productivity indicators in volumetric (MPr) and specific (SMPr) terms contain in the biohydrogen production value the bioreactor volume (MPr) and the amount of biomass in the bioreactor (SMPr), respectively.

Analysis of the volumetric (MPr) and specific (SMPr) productivity showed a non-direct relationship with the applied organic loading rate (conditions $1 / 2 / 4 / 3 / 5 / 6$ ), with greater sensitivity towards influent concentration (conditions 1/3, 2/4 and 5/6 - 50\% increase in the influent concentration: $6.9 / 8.2,5.5 / 8.5$ and $5.7 / 8.4 \mathrm{molH}_{2} \cdot \mathrm{kgTVS}^{-1} \cdot \mathrm{d}^{-1}$ ) than cycle length $(1 / 2 / 5$ and $3 / 4 / 6$ conditions $-50 \%$ reduction in cycle length: $6.9 / 5.5 / 5.7$ and 8.2/8.5/8.4 $\mathrm{molH}_{2} \cdot \mathrm{kgTVS}^{-1} . \mathrm{d}^{-1}$ ). 
Table 3: Concentration of compounds in conditions 1 to 6 .

\begin{tabular}{|c|c|c|c|c|c|c|}
\hline \multirow{2}{*}{ Compounds } & \multicolumn{6}{|c|}{ Molar fraction (\%) } \\
\hline & 1 & 2 & 3 & 4 & 5 & 6 \\
\hline Acetone & - & - & - & - & - & - \\
\hline Methanol & - & - & - & - & - & - \\
\hline Ethanol & 29.0 & 24.6 & 27.5 & 24.1 & 25.8 & 29.1 \\
\hline n-Butanol & 0.4 & 0.3 & 0.2 & 0.3 & 0.2 & 0.3 \\
\hline Acetic acid & 43.0 & 43.4 & 45.9 & 49.1 & 46.0 & 43.9 \\
\hline Propionic acid & 3.7 & 3.8 & 3.9 & 5.1 & 5.0 & 4.6 \\
\hline Isobutyric acid & 3.8 & 4.3 & 3.4 & 2.9 & 3.6 & 3.8 \\
\hline Butyric acid & 13.7 & 15.6 & 12.2 & 12.3 & 12.1 & 12.6 \\
\hline Isovalyric acid & 0.4 & 0.4 & 0.3 & 0.3 & 0.3 & 0.3 \\
\hline Valyric acid & 1.6 & 1.7 & 1.2 & 1.5 & 2.1 & 1.7 \\
\hline Caproic acid & 4.4 & 5.9 & 5.4 & 4.4 & 4.9 & 3.7 \\
\hline Total concentration $\left(\mathrm{mmol} . \mathrm{L}^{-1}\right)$ & 28.2 & 26.7 & 29.1 & 29.2 & 28.2 & 28.5 \\
\hline $\mathrm{H}_{2}(\%)$ & 36 & 34 & 37 & 32 & 38 & 37 \\
\hline $\mathrm{CH}_{4}(\%)$ & 0 & 0 & 0 & 0 & 0 & 0 \\
\hline $\mathrm{CO}_{2}(\%)$ & 64 & 66 & 63 & 68 & 61 & 63 \\
\hline $\mathrm{C}_{\mathrm{H} 2}\left(\mathrm{mmol} . \mathrm{L}^{-1}\right)$ & 7.8 & 6.1 & 9.1 & 7.2 & 7.0 & 9.8 \\
\hline $\mathrm{V}_{\mathrm{G}}\left(\mathrm{NmL} \cdot\right.$ cycle $\left.^{-1}\right)$ & 952 & 836 & 1285 & 1489 & 939 & 1619 \\
\hline
\end{tabular}

*Average standard deviation: $6.8 \%$ (intermediates), $2 \%$ (biogas concentration), 0.4 mmol.L $\mathrm{L}^{-1}$ (hydrogen concentration), and 34 NmL.cycle ${ }^{-1}$ for 6 samples in each condition.

Table 4: Performance indicators in conditions 1 to $6^{*}$.

\begin{tabular}{|c|c|c|c|c|c|c|c|}
\hline \multirow{2}{*}{ Indicators } & \multirow{2}{*}{ Units } & \multicolumn{6}{|c|}{ Conditions } \\
\hline & & 1 & 2 & 3 & 4 & 5 & 6 \\
\hline $\mathrm{AVOL}_{\mathrm{ST}}$ & {$\left[\mathrm{kgSUC} \cdot \mathrm{m}^{-3} \cdot \mathrm{d}^{-1}\right]$} & 8.2 & 10.7 & 12.8 & 14.4 & 18.5 & 26.6 \\
\hline $\mathrm{AVOL}_{\mathrm{CT}}$ & {$\left[\mathrm{kgCOD} \cdot \mathrm{m}^{-3} \cdot \mathrm{d}^{-1}\right]$} & 9.3 & 12.4 & 13.8 & 17.1 & 19.0 & 28.7 \\
\hline $\mathrm{ASOL}_{\mathrm{ST}}$ & {$\left[\right.$ kgSUC.kgTVS $\left.{ }^{-1} \cdot \mathrm{d}^{-1}\right]$} & 1.6 & 2.1 & 2.5 & 2.8 & 5.0 & 5.2 \\
\hline $\mathrm{ASOL}_{\mathrm{CT}}$ & {$\left[\right.$ kgCOD.kgTVS $\left.{ }^{-1} \cdot \mathrm{d}^{-1}\right]$} & 1.8 & 2.4 & 2.7 & 3.4 & 3.7 & 5.6 \\
\hline $\mathrm{RVOL}_{\mathrm{SF}}$ & {$\left[\mathrm{kgSUC} \cdot \mathrm{m}^{-3} \cdot \mathrm{d}^{-1}\right]$} & 8.1 & 10.6 & 12.6 & 14.3 & 17.7 & 24.8 \\
\hline $\mathrm{RVOL}_{\mathrm{CF}}$ & {$\left[\mathrm{kgCOD} \cdot \mathrm{m}^{-3} \cdot \mathrm{d}^{-1}\right]$} & 1.7 & 1.8 & 2.5 & 3.6 & 3.7 & 5.0 \\
\hline $\mathrm{RSOL}_{\mathrm{SF}}$ & {$\left[\right.$ kgSUC. $\left.\operatorname{kgTVS}^{-1} \cdot \mathrm{d}^{-1}\right]$} & 1.5 & 2.0 & 2.4 & 2.7 & 3.4 & 4.9 \\
\hline $\mathrm{RSOL}_{\mathrm{CF}}$ & {$\left[\mathrm{kgCOD} . \mathrm{kgTVS}^{-1} \cdot \mathrm{d}^{-1}\right]$} & 0.33 & 0.35 & 0.49 & 0.70 & 0.73 & 0.98 \\
\hline $\mathrm{n}_{\mathrm{H} 2}$ & {$\left[\mathrm{molH}_{2} \cdot \mathrm{d}^{-1}\right]$} & 0.15 & 0.12 & 0.18 & 0.19 & 0.13 & 0.20 \\
\hline MPr & {$\left[\mathrm{molH}_{2} \cdot \mathrm{m}^{-3} \cdot \mathrm{d}^{-1}\right]$} & 35.2 & 28.1 & 41.8 & 43.4 & 29.1 & 42.8 \\
\hline SMPr & {$\left[\mathrm{molH}_{2} \cdot \mathrm{kgTVS}^{-1} \cdot \mathrm{d}^{-1}\right]$} & 6.9 & 5.5 & 8.2 & 8.5 & 5.7 & 8.4 \\
\hline MYAL $_{S, m}$ & {$\left[\mathrm{molH}_{2} \cdot \mathrm{kgSUC}^{-1}\right]$} & 4.16 & 2.55 & 3.14 & 2.88 & 1.60 & 1.71 \\
\hline MYAL $_{\mathrm{C}, \mathrm{m}}$ & {$\left[\mathrm{molH}_{2} \cdot \mathrm{kgCOD}^{-1}\right]$} & 3.66 & 2.21 & 2.90 & 2.43 & 1.55 & 1.58 \\
\hline MYRL $_{S, m}$ & {$\left[\mathrm{molH}_{2} \cdot \mathrm{kgSUC}^{-1}\right]$} & 4.21 & 2.58 & 3.17 & 2.91 & 1.69 & 1.83 \\
\hline MYRL $_{C, m}$ & {$\left[\mathrm{molH}_{2} \cdot \mathrm{kgCOD}^{-1}\right]$} & 19.6 & 15.6 & 15.7 & 11.5 & 8.09 & 8.98 \\
\hline MYAL $_{\mathrm{S} m}$ & [\%]Acetic acid Route & $18 \%$ & $11 \%$ & $13 \%$ & $12 \%$ & $7 \%$ & $7 \%$ \\
\hline MYAL $_{\mathrm{S}, \mathrm{m}}$ & [\%]Butyric acid Route & $36 \%$ & $22 \%$ & $27 \%$ & $25 \%$ & $14 \%$ & $15 \%$ \\
\hline
\end{tabular}

Acetic acid Route: $\mathrm{C}_{12} \mathrm{H}_{22} \mathrm{O}_{11}+5 \mathrm{H}_{2} \mathrm{O} \rightarrow 4 \mathrm{CH}_{3} \mathrm{COOH}+4 \mathrm{CO}_{2}+8 \mathrm{H}_{2} ; \mathrm{MYAL}_{\mathrm{S}, \mathrm{n}}=8 \mathrm{molH}_{2} \cdot \mathrm{molSUC}^{-1} ; \mathrm{MYAL}_{\mathrm{S}, \mathrm{m}}=23.4 \mathrm{molH}_{2} \cdot \mathrm{kgSUC} \mathrm{Cu}^{-1}$

Butyric acid Route: $\mathrm{C}_{12} \mathrm{H}_{22} \mathrm{O}_{11}+2 \mathrm{H}_{2} \mathrm{O} \rightarrow 2 \mathrm{CH}_{3} \mathrm{CH}_{2} \mathrm{CH}_{2} \mathrm{COOH}+4 \mathrm{CO}_{2}+4 \mathrm{H}_{2} ; \mathrm{MYAL}_{\mathrm{s}, \mathrm{n}}=4 \mathrm{molH} 2 . \mathrm{molSUC}^{-1} ; \mathrm{MYAL}_{\mathrm{s}, \mathrm{m}}=11.7 \mathrm{molH}_{2} \cdot \mathrm{kgSUC}^{-1}$

$*^{*} \mathrm{C}_{\mathrm{X} \text {-TVS }}=0.015 \pm 0.002$ gTVS.gsupport ${ }^{-1}$ and $\mathrm{C}_{\mathrm{X} \text {-TVS }}=5.1 \pm 0.3$ gTVS.L $^{-1}$

Vijaya Bhaskar et al. (2008), Chen et al. (2009) and Sreethawong et al. (2010) obtained MPr of 5.2$11.9,63-106$ and 18-332 $\mathrm{molH}_{2} \cdot \mathrm{m}^{-3} \cdot \mathrm{d}^{-1}$, respectively. Thus, the reactor in this work $\left(28.1-43.4 \mathrm{molH}_{2} \cdot \mathrm{m}^{-3} \cdot \mathrm{d}^{-1}\right)$ under some conditions performed better and under others worse than those in the cited literature, indicating that this configuration may be interesting for application in biohydrogen production.

Indicators based on the applied load, both the applied organic loading rate $\left(\mathrm{COD}-\mathrm{MYAL}_{\mathrm{C}, \mathrm{n}}\right)$ and the applied carbohydrate load $\left(\mathrm{MYAL}_{\mathrm{S}, \mathrm{n}}\right)$, show similar behavior since the organic matter, measured as COD, is the result of carbohydrate (sucrose) added to the influent. Thus, when the increase in applied volumetric organic load was due to the reduction in cycle length at constant influent concentration (conditions $1 / 2 / 5$ and 3/4/6 - 50\% reduction in cycle length: $4.16 /$ 2.55/2.88 and 3.14/2.88/1.71 $\mathrm{molH}_{2} \cdot \mathrm{kgSUC}^{-1}$ ), biohydrogen production was higher for the longer cycle. When the increase in applied volumetric organic 
load was due to the increase in influent concentration at constant cycle length (condition 1/3, 2/4 5/6 - 50\% increase in influent concentration: $4.16 / 3.14,2.55 / 2.88$ and $1.60 / 1.71 \mathrm{molH}_{2} \cdot \mathrm{kgSUC}^{-1}$ ), biohydrogen production was higher at the lowest influent concentration when the cycle length was 4 hours, i.e., was the longest. However, this behavior was the opposite for cycle lengths of 3 and 2 hours; at these cycle lengths the highest biohydrogen yield occurred at the highest influent concentration.

It is noteworthy that this reversal of behavior occurred with values very close to those of hydrogen production. Comparing conditions 4 and $5(2.88 / 1.60$ $\left.\mathrm{molH}_{2} \cdot \mathrm{kgSUC}^{-1}\right)$, i.e. the same applied load with lower influent concentration and shorter cycle length, biohydrogen yield increased for condition 4 . Thus, the reduction in cycle length with a proportional reduction in influent concentration (and the same organic loading rate) seems not to favor biogas production. Comparing these results $\left(\mathrm{MYAL}_{\mathrm{C}} 1.6-\right.$ $4.2 \mathrm{molH}_{2} \cdot \mathrm{kgSUC}^{-1}$ ) with Cheong et al. (2006), Vijaya Bhaskar et al., (2008), Chen et al. (2009) and Sreethawong et al. (2010), who obtained MYAL $\mathrm{C}_{\mathrm{C}}$ of $0.8-4.7,0.7-1.9,2.8-4.7$ and 1.8-8.3, respectively, the performance of the AnSBBR used can be considered satisfactorily.

The indicator based on removed volumetric organic load (COD - MYRL ${ }_{\mathrm{C}, \mathrm{n}}$ ) should not be considered due to the approximately constant behavior and low value of organic matter removal (COD) under all conditions, regardless of the applied load. At this point it is important to mention the result obtained by Bhaskar (2008), who studied biohydrogen production from synthetic effluent under acidogenic anaerobic conditions by varying the applied organic load in the system from 6.3 to $7.9 \mathrm{kgCOD} \cdot \mathrm{m}^{3} \cdot \mathrm{d}^{-1}$ and obtaining a reduction in $\mathrm{MYRL}_{\mathrm{C}, \mathrm{n}}$ from 13.4 to 6.1 $\mathrm{molH}_{2} \cdot \mathrm{kgCOD}^{-1}$.

The indicator based on removed carbohydrate load (sucrose - MYRL S,n $_{\text {) }}$ is possibly the most appropriate indicator for analysis of system performance, as it quantifies biohydrogen production in terms of effectively consumed substrate, showing a relationship between the production of the product of interest (biohydrogen) and consumption of available reagent (sucrose). However, the results were analogous to those for the indicator based on applied carbohydrate load because, undert all conditions, the removal of carbohydrates was similar and high, and no significantly different values were observed when the applied loads changed. Thus, when the applied load was increased due to the reduction in cycle length at constant influent concentration $(1 / 2 / 5$ and $3 / 4 / 6$ conditions - 50\% reduction in cycle length:
4.21/2.58/1.69 and 3.17/2.19/1.83 $\mathrm{molH}_{2} \cdot \mathrm{kgCOD}^{-1}$ ), biohydrogen production increased for the longer cycle.

When the applied load was increased with increasing influent concentration at constant cycle length (conditions 1/3, 2/4 5/6 - 50\% increase in the influent concentration: $4.21 / 3.17,2.58 / 2.91$ and $1.69 / 1.83 \mathrm{molH}_{2} \cdot \mathrm{kgCOD}^{-1}$ ), the behavior was similar to the above, i.e., biohydrogen production was higher at the lowest influent concentration for the 4-h cycle, i.e., the longest cycle. However, this behavior was reversed for 2 and 3-h cycle lengths, i.e., at these cycle lengths the highest biohydrogen production occurred at the highest influent concentration, noting that this reversal of behavior occurred at similar hydrogen production values. Comparing conditions 4/5 $\left(2.91 / 1.69 \mathrm{molH}_{2} \cdot \mathrm{kgCOD}^{-1}\right)$, i.e., same applied load but lower influent concentration and cycle length in condition 5 in relation to condition 4 , there is increased production of biohydrogen in condition 4 , i.e., a reduction in cycle length with a proportional reduction in influent concentration (and the same organic loading rate) seems not to favor biogas production.

Considering the theoretical yield of the production route of acetic and butyric acids (Table 4), the reactor performance reached a maximum of $18 \%$ when using the acetic acid pathway and $36 \%$ when using the butyric acid pathway in condition 1, i.e., the values obtained were below the maximum yield observed in other synthetic wastewater treatments, but remained within the same order of magnitude (Cheong et al., 2006; Vijaya Bhaskar et al., 2008; Chen et al., 2009; Sreethawong et al., 2010).

\section{Profiles Along the Cycle}

Figures 2 to 4 show the profiles of carbohydrates (Figure 2), biogas (Figure $3-\mathrm{H}_{2}, \mathrm{CO}_{2}$ and $\mathrm{CH}_{4}$ ), acetic and butyric/iso-butyric acids (Figure 4 - HBut and HAc), and propionic acid and ethanol (Figure 4 $\mathrm{HPr}$ and $\mathrm{EtOH})$. These profiles were obtained at the end of each condition to observe system behavior and compare with the results obtained when samples were taken at the end of the cycle. The division in two sets, one formed by acetic and butyric/iso-butyric acids and a set formed by ethanol and propionic acid is justified by the fact that the compounds in the first set indicate the formation of hydrogen, whereas the compounds in the second set indicate a reduction in yield and process efficiency. In order to simplify interpretation, the HBut values in these profiles refer to the sum of the values of butyric and iso-butyric acids. 


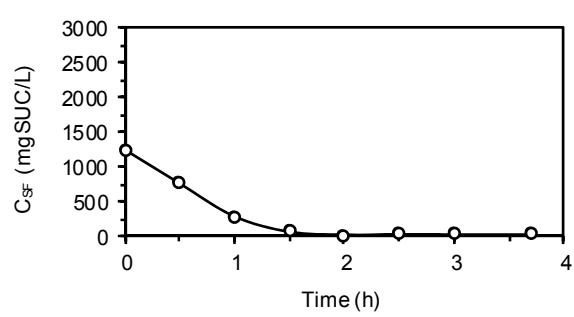

(1)

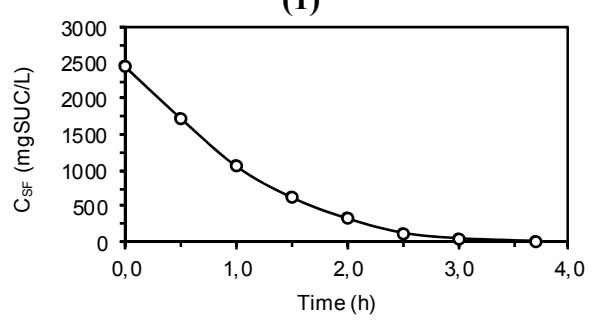

(3)

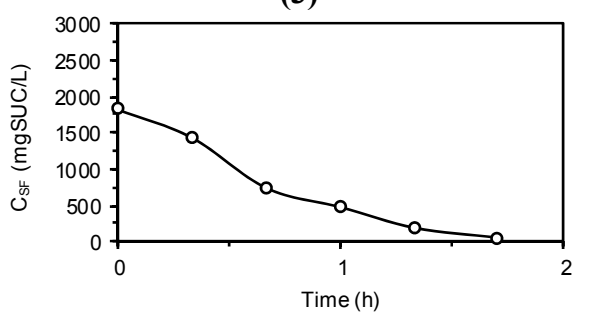

(5)

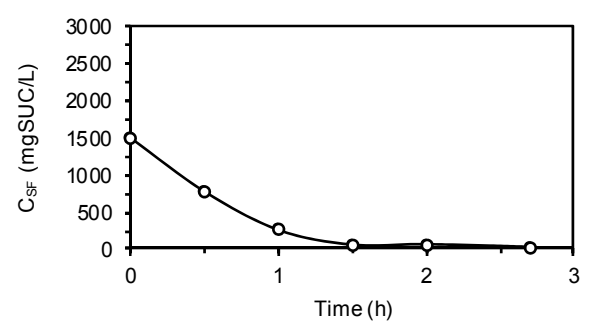

(2)

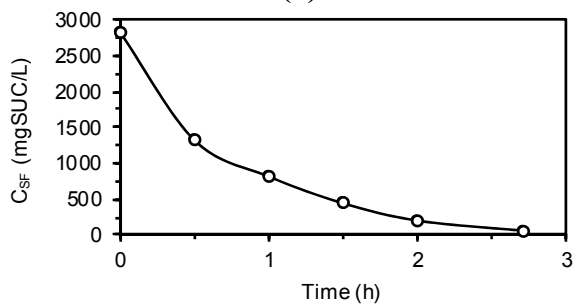

(4)

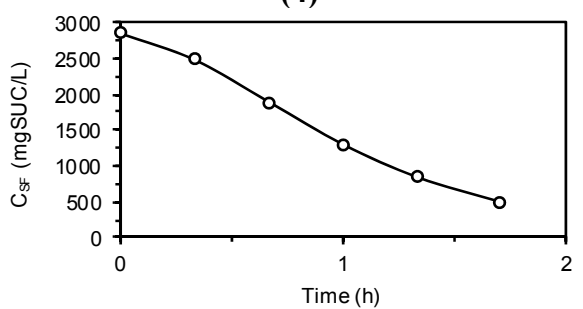

(6)

Figure 2: Profiles of sucrose concentration along the cycles under all conditions.

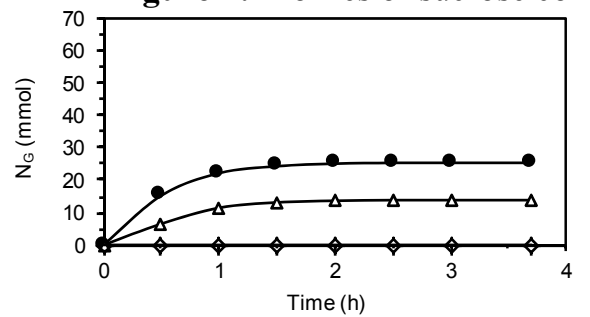

(1)

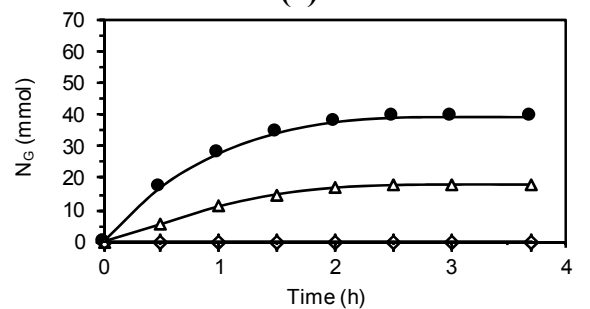

(3)

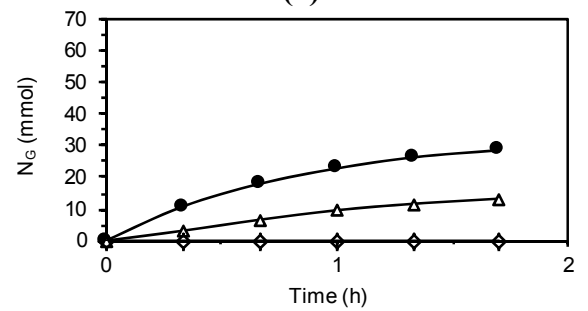

(5)

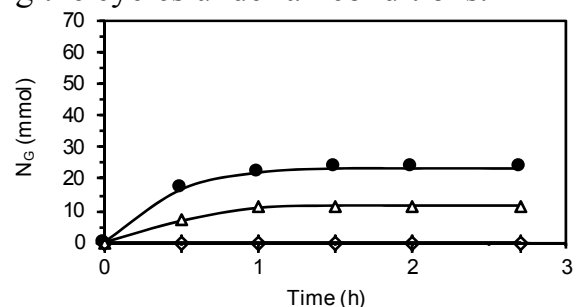

(2)

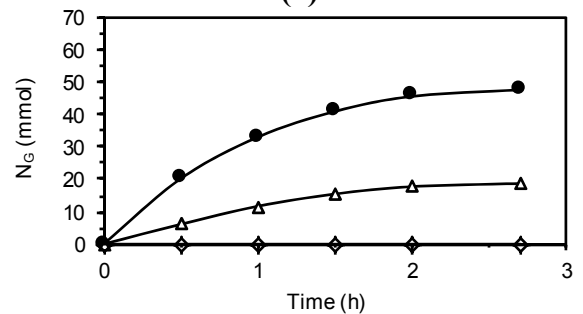

(4)

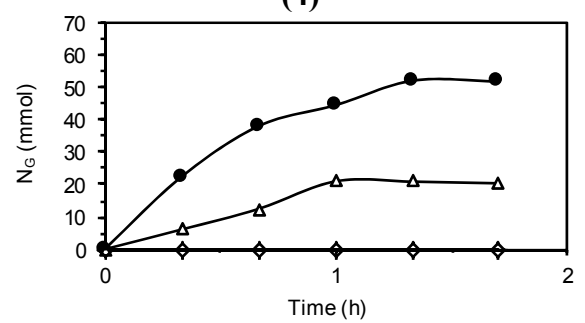

(6)

Figure 3: Profiles of biogas quantity along the cycles under all conditions

$$
\longrightarrow \mathrm{CO}_{2} \longrightarrow \mathrm{H}_{2} \longrightarrow \mathrm{CH}_{4} \text {. }
$$



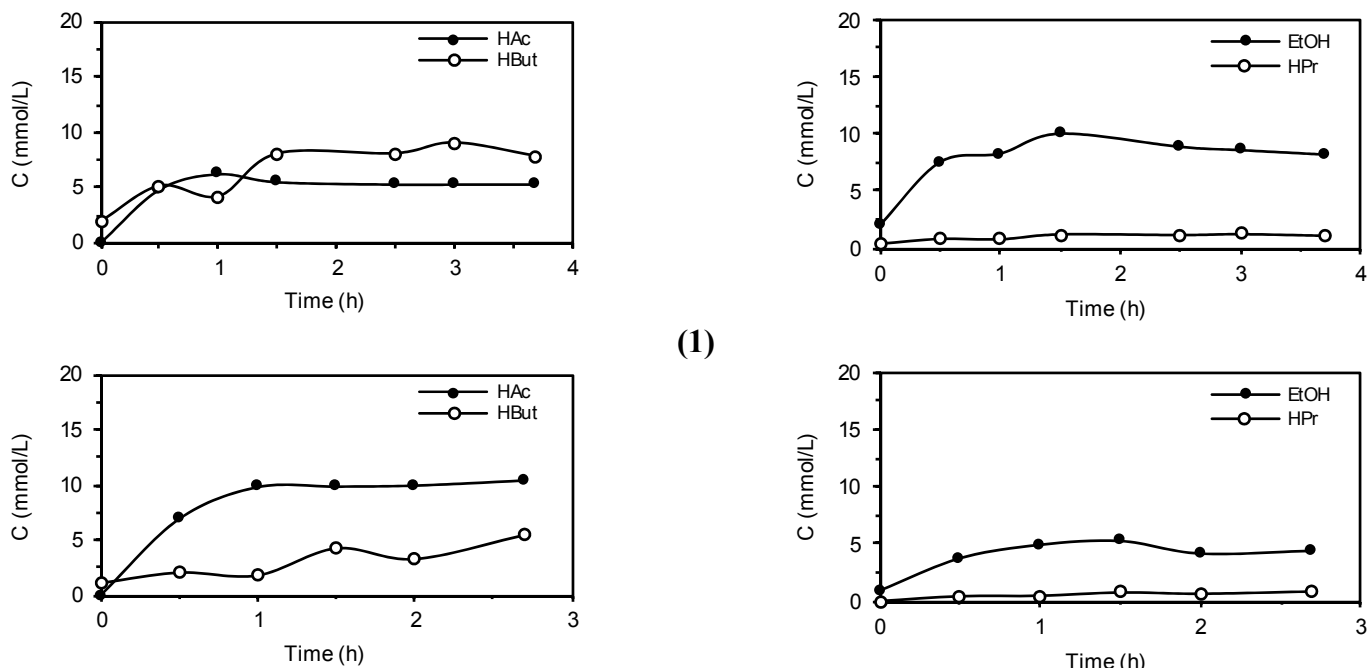

(1)
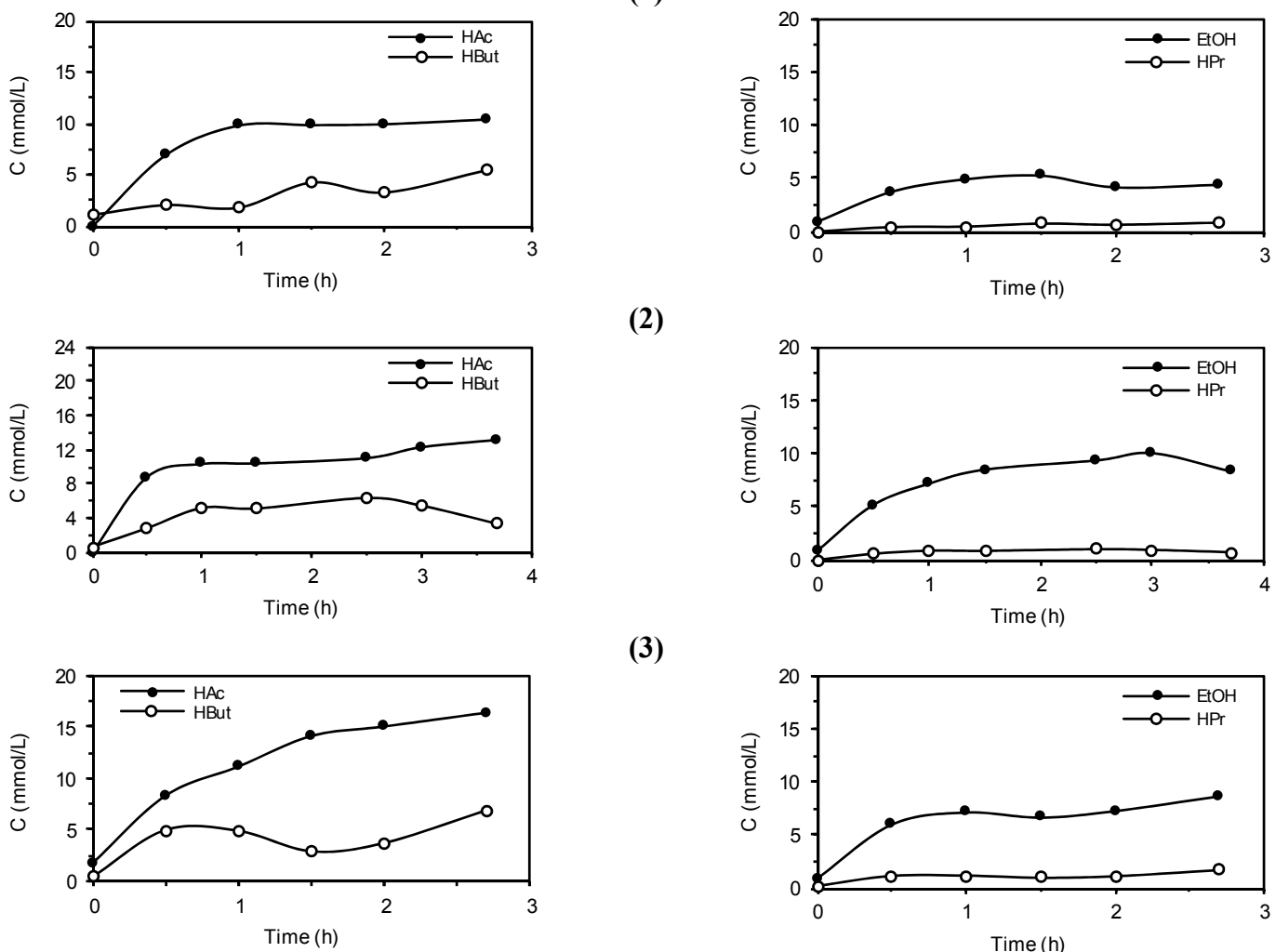

(3)
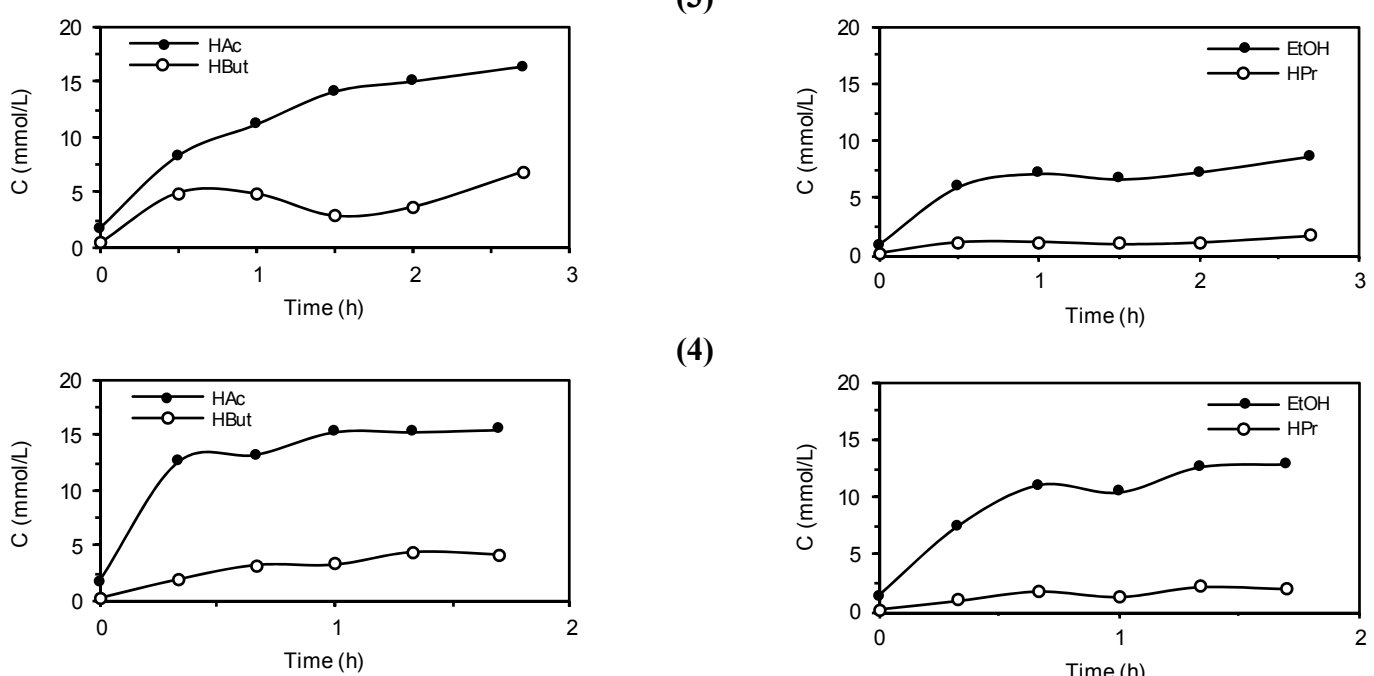

(4)
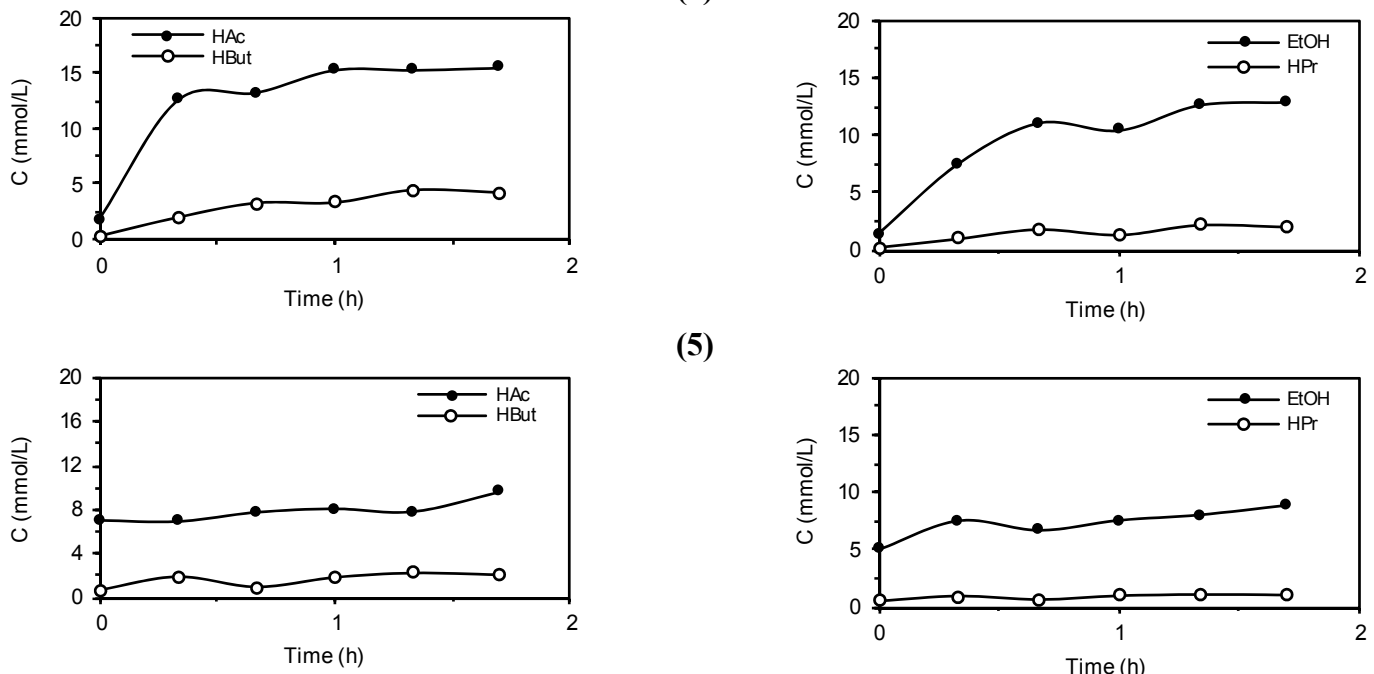

(5)

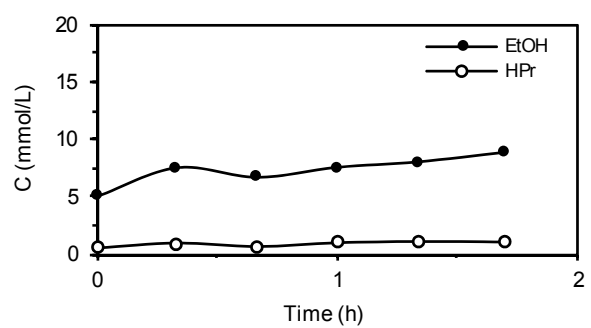

(6)

Figure 4: Profiles of HAc, HBut, HPr and EtOH concentrations along the cycles under all conditions. 
Figure 2 shows the decrease in carbohydrates due to microorganism consumption and Figure 3 shows the formation of biogas, specifically formation of hydrogen and non-formation of methane, where it can be seen that the influent concentration has a stronger effect than cycle length on comparing Conditions $1 / 3,2 / 4$ and 5/6 (different influent concentration and same cycle length) and Conditions $1 / 2 / 5$ and 3/4/6 (different cycle length and same influent concentration). Thus, increasing influent concentration is more effective in obtaining higher initial concentration than decreasing cycle length, which accounts for the higher carbohydrate consumption and hydrogen formation rates.

This behavior is in accordance with the previous discussion on reactor performance, indicating that the best productivity tends to occur at higher organic loads (high influent concentration and low cycle length) as this parameter involves "biochemical generation" of biogas (hydrogen) and the best yield tends to occur at lower organic loads (low influent concentration and high cycle length) because this parameter involves "biochemical consumption" of the substrate.

Figure 3 shows the formation of acetic, propionic, butyric/iso-butyric acids and ethanol, where no clear effect can be seen of influent concentration (Conditions $1 / 3,2 / 4$ and 5/6) and cycle length (Conditions $1 / 2 / 5$ and $3 / 4 / 6$ ). However, it can be seen that the formation of acetic acid was higher in relation to butyric and especially to propionic acid, and that a significant amount of ethanol was present throughout the cycle, which might have reduced the process yield. The reason is probably due to the substrate uptake rate characteristics (simple biodegradation). However, research using glucose and lactose, i.e., other simple substrates but with different up-take rate characteristics, is necessary for more insight into features of the metabolism.

\section{CONCLUSIONS}

The results showed that, in general, it is possible to produce biohydrogen with an AnSBBR with liquid phase recirculation treating sucrose based synthetic wastewater. The system maintained an organic matter (COD) conversion efficiency in the range of $12-20 \%$ and a carbohydrate (sucrose) conversion efficiency in the range of $93-99 \%$ throughout the experimental conditions, i.e., applied and removed organic loads (or influent concentration and cycle length) did not influence system performance. High concentrations of the major volatile acids such as acetic and butyric acids, and of ethanol were obtained in all experimental conditions. Biogas composition under the experimental conditions ranged from 32$39 \% \mathrm{H}_{2}\left(6.1-9.8 \mathrm{mmolH}_{2} \cdot \mathrm{L}^{-1}\right)$ with no $\mathrm{CH}_{4}$. The influence of removed specific organic load (RSOL) on specific molar productivity (SMPr) and molar yield (MYRL) indicated that the influent concentration exerted a stronger effect than cycle length. The experimental conditions 4 and 6 (higher influent concentration and intermediate/shorter cycle length) and condition 1 (lower influent concentration and longer cycle) showed the best results in terms of MPr and MYRL, respectively.

\section{ACKNOWLEDGMENTS}

This study was supported by the Fundação de Amparo à Pesquisa do Estado de São Paulo - FAPESP (São Paulo, Brasil), process numbers 09/15.984-0 and 10/03.874-3 (D.A. Santos). The authors gratefully acknowledge Dr. Baltus C. Bonse for the revision of this paper.

\section{NOTATION}

ASOL $_{\mathrm{CT}}$ Applied specific organic load based on organic matter - non-filtered sample $\left[\mathrm{kgCOD} \cdot \mathrm{m}^{-3} \cdot \mathrm{d}^{-1}\right]$

ASOL $_{\text {ST }}$ Applied specific organic load based on carbohydrate (sucrose) - non-filtered sample $\left[\mathrm{kgSUC} \cdot \mathrm{m}^{-3} \cdot \mathrm{d}^{-1}\right]$

$\mathrm{AVOL}_{\mathrm{CT}}$ Applied volumetric organic load based on organic matter - non-filtered sample $\left[\mathrm{kgCOD} \cdot \mathrm{m}^{-3} \cdot \mathrm{d}^{-1}\right]$

AVOL $_{\text {ST }}$ Applied volumetric organic load based on carbohydrate (sucrose) - non-filtered sample $\left[\mathrm{kgSUC} \cdot \mathrm{m}^{-3} \cdot \mathrm{d}^{-1}\right]$

BA Bicarbonate alkalinity $\left[\mathrm{mgCaCO}_{3} \cdot \mathrm{L}^{-1}\right]$

$\mathrm{C}_{\mathrm{CF}} \quad$ Concentration based on organic matter for filtered samples in the effluent [mgCOD.L ${ }^{-1}$ ]

$\mathrm{C}_{\mathrm{CT}} \quad$ Concentration based on organic matter for unfiltered samples in the effluent [mgCOD.L ${ }^{-1}$ ]

$\mathrm{C}_{\mathrm{CT}, \mathrm{I}} \quad$ Concentration based on organic matter for unfiltered samples in the influent [mgCOD.L ${ }^{-1}$ ]

$\mathrm{C}_{\mathrm{H} 2} \quad$ Concentration of hydrogen $\left[\mathrm{mmol} . \mathrm{L}^{-1}\right]$

$\mathrm{C}_{\mathrm{SF}} \quad$ Concentration based on carbohydrates (sucrose) for filtered samples in the effluent [mgSUC. $\mathrm{L}^{-1}$ or mmolSUC. $\mathrm{L}^{-1}$ ]

$\mathrm{C}_{\mathrm{ST}} \quad$ Concentration based on carbohydrates (sucrose) for unfiltered samples in the 


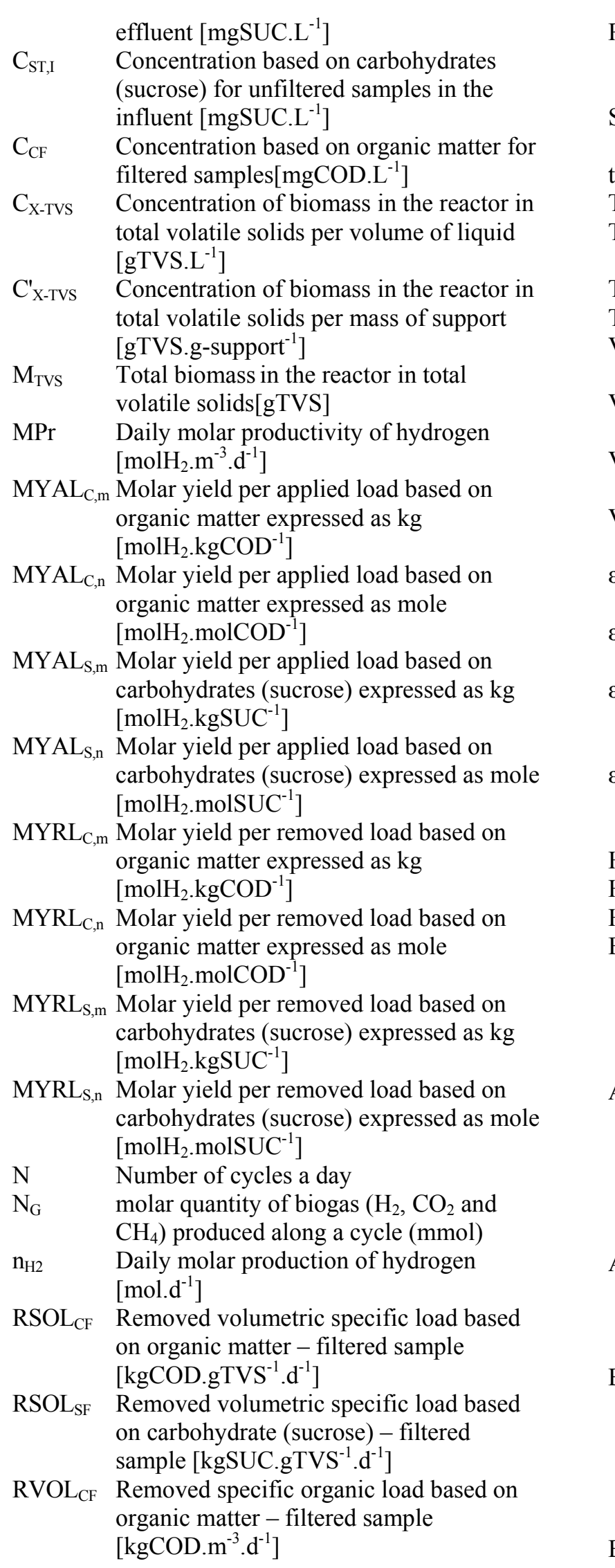

RVOL $_{\mathrm{SF}}$ Removed specific organic load based on carbohydrates (sucrose) - filtered sample $\left[\mathrm{kgSUC} \cdot \mathrm{m}^{-3} \cdot \mathrm{d}^{-1}\right]$

SMPr Daily specific molar productivity of hydrogen $\left[\mathrm{molH}_{2} \cdot \mathrm{kgTVS}^{-1} \cdot \mathrm{d}^{-1}\right]$

$t_{C} \quad$ Cycle length [h.cycle ${ }^{-1}$ ]

TS Total solids concentration [mg. $\mathrm{L}^{-1}$ ]

TSS Total suspended solids concentration [mg.L $\left.\mathrm{L}^{-1}\right]$

TVA Total volatile acids [mgHAC. $\mathrm{L}^{-1}$ ]

TVS Total volatile solids concentration $\left[\mathrm{mg} . \mathrm{L}^{-1}\right.$ ]

VSS Volatile suspended solids concentration [mg.L $\mathrm{L}^{-1}$ ]

$\mathrm{V}_{\mathrm{F}} \quad$ Volume of wastewater fed during the cycle [L.cycle ${ }^{-1}$ ]

$\mathrm{V}_{\mathrm{G}} \quad$ normal volume of biogas $\left(\mathrm{H}_{2}, \mathrm{CO}_{2}\right.$ and $\left.\mathrm{CH}_{4}\right)$ produced along a cycle $(\mathrm{NmL})$

$V_{R} \quad$ Volume of liquid medium in the reactor [L]

$\varepsilon_{\mathrm{CF}} \quad$ Removal efficiency based on organic matter for filtered samples[\%]

$\varepsilon_{\mathrm{CT}} \quad$ Removal efficiency based on organic

matter for unfiltered samples [\%]

$\varepsilon_{\mathrm{SF}} \quad$ Removal efficiency based on carbohydrates (sucrose) for filtered samples [\%]

$\varepsilon_{\mathrm{ST}} \quad$ Removal efficiency based on carbohydrates (sucrose) for unfiltered samples[\%]

HAC Acetic acid

HBut Butyric acid

HPr Propionic acid

EtOH Ethanol

\section{REFERENCES}

Alzate-Gaviria, L. M., Sebastian, P. J., PérezHernández, A., Eapen, D., Comparison of two anaerobic systems for hydrogen production from the organic fraction of municipal solid waste and synthetic wastewater. International Journal of Hydrogen Energy, v. 32, p. 3141-3146 (2007).

Arooj, M., Han, S., Kim, S., Kim, D., Shin, H., Effect of HRT on ASBR converting starch into biological hydrogen. International Journal of Hydrogen Energy, v. 33(22), p. 6509-6514 (2008).

Badiei, M., Jahim, J. M., Anuar, N., Sheikh Abdullah, S. R., Effect of hydraulic retention time on biohydrogen production from palm oil mill effluent in anaerobic sequencing batch reactor. International Journal of Hydrogen Energy, v. 36, p. 5912-5919 (2011).

Bezerra, R. A., Rodrigues, J. A. D., Ratusznei, S. M., 
Canto, C. S. A., Zaiat, M., Effect of organic load on the performance and methane production of an AnSBBR treating effluent from biodiesel production. Applied Biochemistry and Biotechnology, v. 165 , p. $347-368$ (2011).

Chen, W., Sung, S., Chen, S., Biological hydrogen production in an anaerobic sequencing batch reactor: $\mathrm{pH}$ and cyclic duration effects. International Journal of Hydrogen Energy, v. 34, p. $227-$ 234 (2009).

Cheong, D.-Yeol., Hansen, C. L., Stevens, D. K., Production of bio-hydrogen by mesophilic anaerobic fermentation in an acid-phase sequencing batch reactor. Biotechnology, v. 96, p. 421-432 (2007).

Das, D., Veziroglu, T. N., Hydrogen production by biological processes: A survey of literature. International Journal of Hydrogen Energy, v. 26, p. 13-28 (2001).

Davila-Vazquez, G., Arriaga, S., Alatriste-Mondragón, F., Fermentative biohydrogen production: Trends and perspectives. Reviews in Environmental Science and Bio/Technology, v. 7, p. $27-45$ (2007).

Dubois, S. M., Gilles, K. A., Hamilton, J. L., Rebers, P. A., Smith, F., Colorimetric methods for determination of sugar and related substance. Analytical Chemistry, v. 228, p. 13-21 (1956).

Ito, T., Nakashimada, Y., Senba, K., Matsui, T., Nishio, N., Hydrogen and ethanol production from glycerol containing wastes discharges after biodiesel manufacturing process. Journal of Bioscience and Bioengineering, v. 100, p. 260-265 (2005).

Jeong, T., Cha, G., Yoo, I., Kim, D., Hydrogen production from waste activated sludge by using separation membrane acid fermentation reactor and photosynthetic reactor. International Journal of Hydrogen Energy, v. 32, p. 525-530 (2007).

Kawagoshi, Y., Hino, N., Fujimoto, A., Effect of inoculum conditioning on hydrogen fermentation and $\mathrm{pH}$ effect on bacterial community relevant to hydrogen production. Journal of Bioscience and Bioengineering, v. 100, p. 524-530 (2005).

Khanal, S., Chen, W., Sung, S., Biological hydrogen production: effects of $\mathrm{pH}$ and intermediate products. International Journal of Hydrogen Energy, v. 29, p. 1123-1131 (2003).

Leite, J. A. C., Fernandes, B. S., Pozzi, E., Barboza, M., Zaiat, M., Application of an anaerobic packedbed bioreactor for the production of hydrogen and organic acids. International Journal of Hydrogen Energy, v. 33, p. 579-586 (2008).

Li, C., Fang, H., Fermentative hydrogen production from wastewater and solid wastes by mixed cul- tures. Critical Reviews in Environmental Science and Technology, v. 37, p. 1-39 (2007).

Lin, C., Lay, C., A nutrient formulation for fermentative hydrogen production using anaerobic sewage sludge microflora. International Journal of Hydrogen Energy, v. 30, p. 285-292 (2005).

Lin, C., Lay, C., Carbon/nitrogen ratio effect on fermentative hydrogen production by mixed microflora. International Journal of Hydrogen Energy, v. 29, p. 41-45 (2004a).

Lin, C., Lay, C., Effects of carbonate and phosphate concentrations on hydrogen production using anaerobic sewage sludge microflora. International Journal of Hydrogen Energy, 29, 275-281 (2004b).

Liu, X., Zhu, Y., Yang, S. T., Butyric acid and hydrogen production by Clostridium tyrobutyricum ATCC 25755 and mutants. Enzyme and Microbial Technology, v. 38, p. 521-528 (2006).

Lovato, G., Bezerra, R. A., Rodrigues, J. A. D., Ratusznei, S. M., Zaiat, M., Effect of feed strategy on methane production and performance of an AnSBBR treating effluent from biodiesel production. Applied Biochemistry and Biotechnology, v. 166, p. 2007-2029 (2012).

Mohan, S. V., Babu, V. L., Sarma, P., Anaerobic biohydrogen production from dairy wastewater treatment in sequencing batch reactor (ASBR): Effect of organic loading rate. Enzyme and Microbial Technology, v. 41, p. 506-515 (2007).

Mohanakrishna, G., Venkata Subhash, G., Venkata Mohan, S., Adaptation of biohydrogen producing reactor to higher substrate load: Redox controlled process integration strategy to overcome limitations. International Journal of Hydrogen Energy, v. 36, p. 8943-8952 (2011).

Mu, Y., Zheng, X., Yu, H., Zhu, R., Biological hydrogen production by anaerobic sludge at various temperatures. International Journal of Hydrogen Energy, v. 31, p. 780-785 (2006).

Nishio, N., Nakashimada, Y., Recent development of digestion process for energy recovery from wastes. Journal of Bioscience and Bioengineering, v. 103, p. 105-112 (2007).

Novaes, L. F., Borges, L. O., Rodrigues, J. A. D., Ratusznei, S. M., Zaiat, M., Foresti, E., Effect of fill time on the performance of pilot-scale ASBR and AnSBBR applied to sanitary wastewater treatment. Applied Biochemistry and Biotechnology, v. 162, p. 885-899 (2010).

O-Thong, S., Prasertsan, P., Intrasungkha, N., Dhamwichukorn, S., Birkeland, N., Optimization of simultaneous thermophilic fermentative hydrogen production and COD reduction from palm oil mil effluent by Thermoanaerobaterium-rich 
sludge. International Journal of Hydrogen Energy, v. 33, p. 1221-1231 (2008).

Oztekin, R., Kapdan, I., Kargui, F., Argun, H., Optimization of media composition for hydrogen gas production from hydrolyzed wheat starch by dark fermentation. International Journal of Hydrogen Energy, v. 33, p. 4083-4090 (2008).

Ren, N., Guo, W., Wang, X., Effects of different pretreatment methods on fermentation types and dominant bacteria for hydrogen production. International Journal of Hydrogen Energy, v. 33, p. 4318-4324 (2008).

Silva, R. C., Ratusznei, S. M., Rodrigues, J. A. D., Zaiat, M., Anaerobic treatment of industrial biodiesel wastewater by an ASBR for methane production. Applied Biochemistry and Biotechnology, v. 170, p. 105-118 (2013).

Sreethawong, T., Niyamapa, T., Neramitsuk, H., Hydrogen production from glucose-containing wastewater using an anaerobic sequencing batch reactor: Effects of COD loading rate, nitrogen content, and organic acid composition. Chemical Engineering Journal, v. 160, p. 322-332 (2010).

Standard Methods for the Examination of Water and Wastewater APHA, AWWA, WPCF. 19th Edition, American Public Health Association, Washington (1995).

Tanisho, S., Ishiwata, Y., Continuous hydrogen production from molasses by fermentation using urethane foam as a supprt of flocks. International Association for Hydrogen Energy, v. 20, p. 541545 (1995).

Turcot, J., Bisaillon, A., Hallenbeck, P., Hydrogen production by continuous cultures of Escherichia coli under different nutrient regimes. Interna- tional Journal of Hydrogen Energy, 33, 14651470 (2008).

Vijaya Bhaskar, Y., Venkata Mohan, S., Sarma, P. N., Effect of substrate loading rate of chemical wastewater on fermentative biohydrogen production in biofilm configured sequencing batch reactor. Bioresource Technology, v. 99, p. 6941-6948 (2008).

Wang, J., Wan, W., Factors influencing fermentative hydrogen production: A review. International Journal of Hydrogen Energy, v. 34, p. 799-811 (2009b).

Wang, X., Monis, P. T., Saint, C. P., Jin, B., Biochemical kinetics of fermentative hydrogen production by Clostridium butyricum W5. International Journal of Hydrogen Energy, v. 34, p. 791798 (2009a).

Wang, Y., Zhao, Q., Mu, Y., Biohydrogen production with mixed anaerobic cultures in the presence of high-concentration acetate. International Journal of Hydrogen Energy, v. 33, p. 1164-1171 (2008).

Wu, S. Y., Lin, C. N., Chang, J. S., Hydrogen production with immobilized sewage sludge in threephase fluidized-bed bioreactors. Biotechnology Progress, v. 19, p. 828-832 (2003).

Wu, X., Yao, W., Zhu, J., Effect of $\mathrm{pH}$ on continuous biohydrogen production from liquid swine manure with glucose supplement using an anaerobic sequencing batch reactor. International Journal of Hydrogen Energy, v. 35, p. 6592-6599 (2010).

Zhang, Z., Show, K., Tay, J., Effect of hydraulic retention time on biohydrogen production and anaerobic microbial community. Process Biochemistry, v. 41, p. 2118-2123 (2006). 